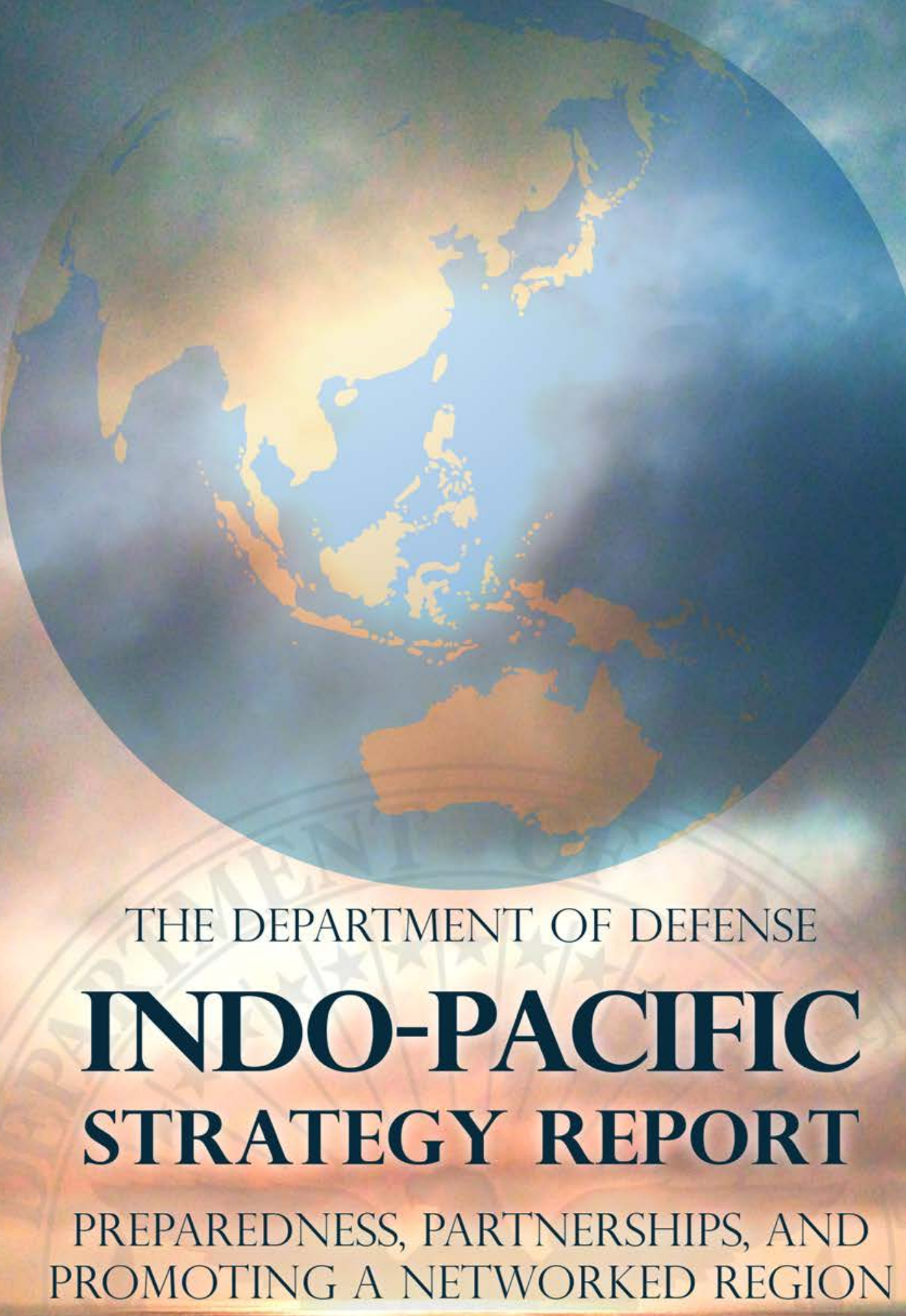


This page left intentionally blank 


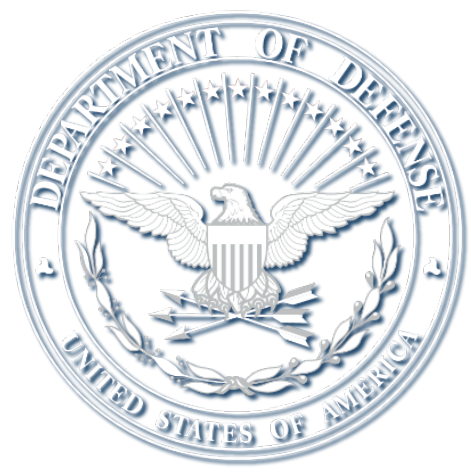

\section{THE DEPARMENT OF DEFENSE}

\section{INDO-PACIFIC STRATEGY REPORT}

Preparedness, Partnerships, and Promoting a Networked Region

$$
\text { June 1, } 2019
$$

The estimated cost of this report or study for the Department of Defense is approximately $\$ 128,000$ for the 2019 Fiscal Year. This includes $\$ 18,000$ in expenses and $\$ 110,000$ in DoD labor.

Generated on 2019June01 RefID: 0-1C9F36A 


\section{MESSAGE FROM THE SECRETARY OF DEFENSE}

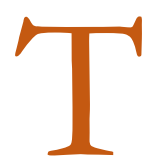

he Indo-Pacific is the Department of Defense's priority theater. The United

States is a Pacific nation; we are linked to our Indo-Pacific neighbors through unbreakable bonds of shared history, culture, commerce, and values. We have an enduring commitment to uphold a free and open IndoPacific in which all nations, large and small, are secure in their sovereignty and able to pursue economic growth consistent with accepted international rules, norms, and principles of fair competition.

The continuity of our shared strategic vision is uninterrupted despite an increasingly complex security environment. Inter-state strategic competition, defined by geopolitical rivalry between free and repressive world order visions, is the primary concern for U.S. national security. In particular, the People's Republic of China, under the leadership of the Chinese Communist Party, seeks to reorder the region to its advantage by leveraging military modernization, influence operations, and predatory economics to coerce other nations.

In contrast, the Department of Defense supports choices that promote long-term peace and prosperity for all in the Indo-Pacific. We will not accept policies or actions that threaten or undermine the rules-based international order - an order that benefits all nations. We are committed to defending and enhancing these shared values.

The National Security Strategy and the National Defense Strategy articulate our vision to compete, deter, and win in this environment. Achieving this vision requires combining a more lethal Joint Force with a more robust constellation of allies and partners. Increased investments in these imperatives will sustain American influence in the region to ensure favorable balances of power and safeguard the free and open international order.

This 2019 Department of Defense Indo-Pacific Strategy Report (IPSR) affirms the enduring U.S. commitment to stability and prosperity in the region through the pursuit of preparedness, partnerships, and the promotion of a networked region. 
- Preparedness - Achieving peace through strength and employing effective deterrence requires a Joint Force that is prepared to win any conflict from its onset. The Department, alongside our allies and partners, will ensure our combat-credible forces are forward-postured in the region. Furthermore, the Joint Force will prioritize investments that ensure lethality against high-end adversaries.

- Partnerships - Our unique network of allies and partners is a force multiplier to achieve peace, deterrence, and interoperable warfighting capability. The Department is reinforcing its commitment to established alliances and partnerships, while also expanding and deepening relationships with new partners who share our respect for sovereignty, fair and reciprocal trade, and the rule of law.

- Promotion of a Networked Region - The Department is strengthening and evolving U.S. alliances and partnerships into a networked security architecture to uphold the international rules-based order. The Department also continues to cultivate intra-Asian security relationships capable of deterring aggression, maintaining stability, and ensuring free access to common domains.

Advancing this Indo-Pacific vision requires an integrated effort that recognizes the critical linkages between economics, governance, and security - all fundamental components that shape the region's competitive landscape. The Department of Defense, in partnership with other U.S. Government Departments and Agencies, regional institutions, and regional allies and partners, will continue to diligently uphold a rules-based order that ensures peace and prosperity for all.

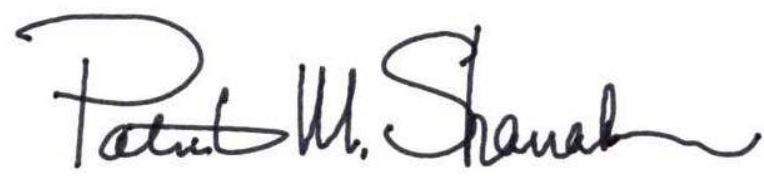

Patrick M. Shanahan Acting Secretary of Defense 
This page left intentionally blank 


\section{CONTENTS}

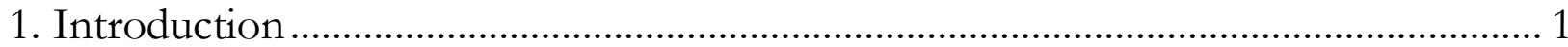

1.1. America's Historic Ties to the Indo-Pacific ..................................................... 2

1.2. Vision and Principles for a Free and Open Indo-Pacific.................................. 3

2. Indo-Pacific Strategic Landscape: Trends and Challenges...................................... 7

2.1. The People's Republic of China as a Revisionist Power...................................... 7

2.2. Russia as a Revitalized Malign Actor............................................................. 11

2.3. The Democratic People’s Republic of Korea as a Rogue State ......................... 12

2.4. Prevalence of Transnational Challenges ........................................................ 13

3. U.S. National Interests and Defense Strategy.................................................. 15

3.1. U.S. National Interests ................................................................................ 15

3.2. U.S. National Defense Strategy ................................................................... 16

4. Sustaining U.S. Influence to Achieve Regional Objectives................................... 17

4.1. Line of Effort 1: Preparedness..................................................................... 17

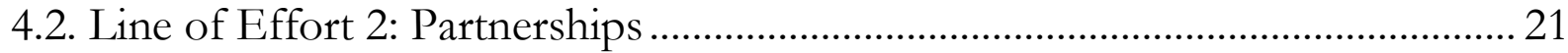

4.3. Line of Effort 3: Promoting a Networked Region .......................................... 44

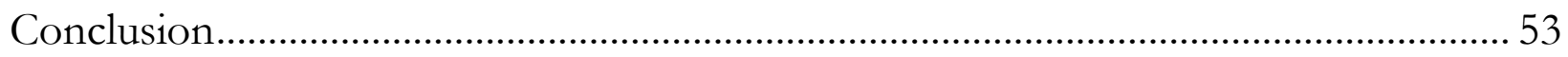

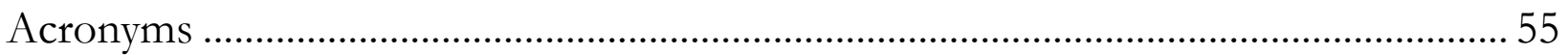


INDO-PACIFIC STRATEGY REPORT

This page left intentionally blank 


\section{INTRODUCTION}

he Indo-Pacific is the single most consequential region for America's future. Spanning a vast stretch of the globe from the west coast of the United States to the western shores of India, the region is home to the world's most populous state, most populous democracy, and largest Muslim-majority state, and includes over half of the earth's population. Among the 10 largest standing armies in the world, 7 reside in the Indo-Pacific; and 6 countries in the region possess nuclear

"The story of the Indo-Pacific in recent decades is the story of what is possible when people take ownership of their future...this region has emerged as a beautiful constellation of nations, each its own bright star, satellites to none."

President Donald J. Trump, speech at the APEC CEO Summit, weapons. Nine of the world's 10 busiest seaports are in the region, and 60 percent of global maritime trade transits through Asia, with roughly one-third of global shipping passing through the South China Sea alone.

November 10, 2017

The United States is a Pacific nation and has five Pacific states: Hawaii, California, Washington, Oregon, and Alaska, as well as Pacific territories on both sides of the International Date Line, including: Guam, American Samoa, 
Wake Island, and the Commonwealth of Northern Mariana Islands (CNMI). American businesses have traded in Asia since the 18th century, and today, within the Asia-Pacific Economic Cooperation (APEC), America's annual two-way trade with the region is $\$ 2.3$ trillion, with U.S. foreign direct investment of $\$ 1.3$ trillion in the region - more than China's, Japan's, and South Korea's combined.

The Indo-Pacific contributes two-thirds of global growth in gross domestic product (GDP) and accounts for 60 percent of global GDP. This region includes the world's largest economies - the United States, China, and Japan - and six of the world's fastest growing economies - India, Cambodia, Laos, Burma, Nepal, and the Philippines. A quarter of U.S. exports go to the Indo-Pacific, and exports to China and India have more than doubled over the past decade. This is made possible by free and open trade routes through the air, sea, land, space, and cyber commons that form the current global system.

\subsection{America's Historic Ties to the Indo-Pacific}

The United States is a Pacific nation. Our ties to the Indo-Pacific are forged by history, and our future is inextricably linked. We have contributed both blood and treasure to sustain the freedoms, openness, and opportunity of this region. Our presence secures the vital sea lanes of the Indo-Pacific that underpin global commerce and prosperity. Our leaders, diplomats, military forces, and businesses helped frame and strengthen the international system of clear and transparent rules; peaceful resolution of disputes; and the rule of law that has been vital to the region's relative security and growing prosperity.

The past, present, and future of the United States are interwoven with the Indo-Pacific. Our engagement in the Indo-Pacific dates back more than two centuries, based on the pursuit of the shared prosperity that comes from fair and reciprocal trade, open commerce, and freedom of navigation. In 1784, within months of signing the Treaty of Paris, the United States sent a trading ship, the EMPRESS OF CHINA to inaugurate commercial ties with China. In 1804, President Thomas Jefferson sent the explorers - Lewis and Clark - on an expedition to our Pacific Coast, which Jefferson recognized as the gateway for increased trade and commerce. By 1817, Congress approved the first full-time Pacific deployment of a U.S. warship. In the early 19th century, we began our relationship with the Kingdom of Thailand and thereafter negotiated to open Japan to global trade in the 1850s. 
At the close of the 19th century, the United States established an "Open Door" policy towards China, promoting equal opportunity for trade and commerce in China, and respect for China's sovereignty.

In the 20th century, the United States expanded its role in the region as we confronted imperialism and fascism and held the line against communism during the Cold War. The early 1950s marked several milestones - the signing of the Mutual Defense Treaty between the Republic of the Philippines and the United States in August 1951 and the signing of the Australia, New Zealand, and United States Security Treaty in September 1951 - both of which sought to bring stability to the region. In the seven decades that followed the Second World War, based on a foundation of the U.S. system of alliances and our forward deployed forces, the Indo-Pacific was largely peaceful, and we helped create the stability necessary for economic prosperity in the United States and the region.

In pursuit of partnership, not domination, the United States worked with Japan and South Korea after the Second World War to forge alliances and stimulate an economic boom in both countries. In Taiwan, U.S. aid helped create an open, democratic society that allowed the island to blossom into a high-tech powerhouse. In the 1970s and 1980s, the United States invested in Hong Kong, Singapore, and other Southeast Asian economies and supported foundational institutions like the Association for Southeast Asian Nations (ASEAN), the APEC Forum, and the Asian Development Bank, all contributing to growth in the region. Simultaneously, the United States established formal diplomatic relations with China in 1979, which facilitated economic exchange and extended America's consistent policy approach of a free, open market and equal trading opportunity for merchants of all nationalities operating in the region. At the turn of the 21st century, the United States advocated for China's admission into the World Trade Organization, with the belief that economic liberalization would bring China into a greater partnership with the United States and the free world.

As history has demonstrated and the future necessitates, the United States will continue to play a key role as a force for regional stability in the Indo-Pacific in support of U.S. diplomatic and economic aspirations. To do so, the United States must be prepared by sustaining a credible combat-forward posture; strengthening alliances and building new partnerships; and promoting an increasingly networked region. These actions will enable the United States to preserve a free and open IndoPacific where sovereignty, independence, and territorial integrity are safeguarded.

\subsection{Vision and Principles for a Free and Open Indo-Pacific}

In 2017, President Trump announced our nation's vision for a free and open Indo-Pacific at the APEC Summit in Vietnam, and our commitment to a safe, secure, prosperous, and free region that benefits all nations. This vision flows from common principles that underpin the current international order, which has benefited all countries in the region - principles we have a shared responsibility to uphold: 
1. Respect for sovereignty and independence of all nations;

2. Peaceful resolution of disputes;

3. Free, fair, and reciprocal trade based on open investment, transparent agreements, and connectivity; and,

4. Adherence to international rules and norms, including those of freedom of navigation and overflight.

Our vision for a free Indo-Pacific is one in which all nations, regardless of size, are able to exercise their sovereignty free from coercion by other countries. At the national-level, this means good governance and the assurance that citizens can enjoy their fundamental rights and liberties. Our vision for an open Indo-Pacific is one that promotes sustainable growth and connectivity in

"The U.S. offers strategic partnerships, not strategic dependence. Alongside our allies and partners, America remains committed to maintaining the region's security, its stability, and its economic prosperity."

- Then-Secretary of Defense James N. Mattis, speech at the Shangri-La Dialogue, June 1, 2018 the region. This means all nations enjoy access to international waters, airways, and cyber and space domains, and are able to pursue peaceful resolution of territorial and maritime disputes. On an economic level, this means fair and reciprocal trade, open investment environments, and transparent agreements between nations.

Our vision for a free and open Indo-Pacific recognizes the linkages between economics, governance, and security that are part of the competitive landscape throughout the region, and that economic security is national security. In order to achieve this vision, we will uphold the rule of law, encourage resilience in civil society, and promote transparent governance - all of which expose malign influences that threaten economic development everywhere. Our vision aspires to a regional order in which independent nations can both defend their interests and compete fairly in the international marketplace. It is a vision which recognizes that no one nation can or should dominate the IndoPacific.

In recognition of the region's need for greater investment, including infrastructure investment, the United States seeks to invigorate our development and finance institutions to enable us to become better, more responsive partners. U.S. Departments and Agencies will work with regional allies and partners to provide end-to-end solutions that build tangible products and transfer experience. Ultimately, the maintenance of a free and open order sustains regional development because a wellfunctioning and transparent marketplace incentivizes global commercial investments that outpaces any state's unique resources. The United States is not alone in its pursuit of a free and open IndoPacific - many of our allies and partners share these principles and values: 
"We must ensure that these waters are a public good that bring peace and prosperity to all people without discrimination into the future."

Prime Minister of Japan, Shinzo Abe, policy speech to the $196^{\text {th }}$ session of the Diet January 22, 2018

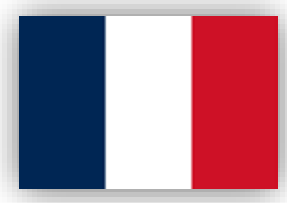

"Now what is important is to preserve a rules-based development in the region. It's to preserve the necessary balances in the region."

President of France, Emmanuel Macron, speech during a state visit to Australia May 2, 2018

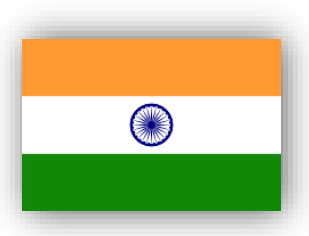

"...rules and norms should be based on the consent of all, not on the power of the few."

Prime Minister of India, Narendra Modi, keynote address at the Shangri-La Dialogue June 1, 2018

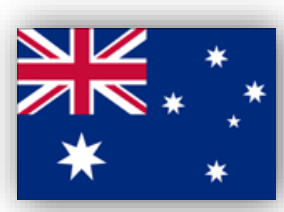

"We want a rules-based system that respects the sovereignty and the independence of every single country and a commitment then to regional security that is always the precondition for prosperity."

Prime Minister of Australia, Scott Morrison, address at the APEC CEO Summit November 17, 2018

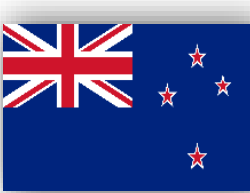

"Collective solutions to shared challenges in the Pacific require strong and vibrant regionalism, with institutions that can convert political will into action, supported by partners who align their efforts with the region's priorities."

\footnotetext{
Deputy Prime Minister and Minister of Foreign Affairs for New Zealand, Winston Peters, address at Georgetown University

December 15, 2018
} 
A free and open Indo-Pacific rests on a foundation of mutual respect, responsibility, priorities, and accountability. While we unapologetically represent U.S. values and beliefs, we do not seek to impose our way of life on others. In order to maintain the regional dynamism that benefits all, each country in the region has a shared responsibility to contribute and sustain it - for the regional order will not survive on its own. We will uphold our commitments, but we will rely on allies and partners to contribute their fair share, including by investing to modernize their defense capabilities.

Advancing this vision is a whole-of-government priority that draws on the strengths and values of American society. As Secretary of State Michael Pompeo has said, "The American people and the whole world have a stake in the Indo-Pacific's peace and prosperity. It's why the Indo-Pacific must be free and open.”

Our whole-of-government commitment was reflected at the Indo-Pacific Business Forum in 2018, as Secretary of State Pompeo, Secretary of Commerce Wilbur Ross, U.S. Agency for International Development Administrator Mark Green, and other Cabinet-level officials launched new initiatives to expand U.S. public and private investment in Indo-Pacific infrastructure, energy markets, and digital economy. We also established new development finance partnerships with Japan, Australia, Canada, and the European Union, supported by significant new resources and authorities in the Better Utilization of Investments Leading to Development Act or the BUILD Act, which President Trump signed into law in October 2018. The following month, Vice President Michael Pence announced efforts to coordinate with Japan on $\$ 10$ billion in regional energy investment, establish a U.S.-ASEAN Smart Cities Partnership, and launch a five-country partnership for electrification in Papua New Guinea. The Vice President also announced the Indo-Pacific Transparency Initiative to help countries attract high-quality investment and counter corruption and coercive threats to their sovereignty, by strengthening civil society and good governance. Furthermore, the Asia Reassurance Initiative Act, a major bipartisan legislation, was signed into law by President Trump on December 31, 2018. This legislation enshrines a generational whole-of-government policy framework that demonstrates U.S. commitment to a free and open Indo-Pacific region and includes initiatives that promote sovereignty, rule of law, democracy, economic engagement, and regional security.

As the region grows in population and economic weight, U.S. strategy will adapt to ensure that the Indo-Pacific is increasingly a place of peace, stability, and growing prosperity - and not one of disorder, conflict, and predatory economics. Embedding these free and open principles will require efforts across the spectrum of our agencies and capabilities: diplomatic initiatives, governance capacity building, economic cooperation and commercial advocacy, and military cooperation. 


\section{INDO-PACIFIC STRATEGIC LANDSCAPE: TRENDS AND CHALLENGES}

\subsection{The People's Republic of China as a Revisionist Power}

China's economic, political, and military rise is one of the defining elements of the 21 st century. Today, the Indo-Pacific increasingly is confronted with a more confident and assertive China that is willing to accept friction in the pursuit of a more expansive set of political, economic, and security interests.

Perhaps no country has benefited more from the free and open regional and international system than China, which has witnessed the rise of hundreds of millions from poverty to growing prosperity and security. Yet while the Chinese people aspire to free markets, justice, and the rule of law, the People's Republic of China (PRC), under the leadership of the Chinese Communist Party (CCP), undermines the international system from within by exploiting its benefits while simultaneously eroding the values and principles of the rules-based order. With more than half of the world's Muslim population living 
in the Indo-Pacific, the region views the PRC's systematic mistreatment of Uighurs, Kazakhs, and other Muslims in Xinjiang - including pervasive discrimination, mass detention, and disappearances - with deep concern. China's violation of international norms also extends abroad. Chinese nationals acting in association with the Chinese Ministry of State Security were recently indicted for conducting global campaigns of cyber theft that targeted intellectual property and confidential business and technological information at managed service providers. China has continued to militarize the South China Sea by placing anti-ship cruise missiles and long-range surface-to-air missiles on the disputed Spratly Islands and employing paramilitary forces in maritime disputes vis-à-vis other claimants. In the air, the People's Liberation Army (PLA) has increased patrols around and near Taiwan using bomber, fighter, and surveillance aircraft to signal Taiwan. China additionally employs non-military tools coercively, including economic tools, during periods of political tensions with countries that China accuses of harming its national interests.

\section{The People's Republic of China's Military Modernization and Coercive Actions}

As China continues its economic and military ascendance, it seeks Indo-Pacific regional hegemony in the near-term and, ultimately global preeminence in the long-term. China is investing in a broad range of military programs and weapons, including those designed to improve power projection; modernize its nuclear forces; and conduct increasingly complex operations in domains such as cyberspace, space, and electronic warfare operations. China is also developing a wide array of anti-access/area denial (A2/AD) capabilities, which could be used to prevent countries from operating in areas near China's periphery, including the maritime and air domains that are open to use by all countries.

In 2018, China's placement of anti-ship cruise missiles and long-range surface-to-air missiles on the disputed Spratly Islands violated a 2015 public pledge by the Chairman of the CCP Xi Jinping that "China does not intend to pursue militarization" of the Spratly Islands. China's use of military presence in an attempt to exert de facto control over disputed areas is not limited to the South China Sea. In the East China Sea, China patrols near the Japan-administered Senkaku Islands with maritime law enforcement ships and aircraft. These actions endanger the free flow of trade, threaten the sovereignty of other nations, and undermine regional stability. Such activities are inconsistent with the principles of a free and open Indo-Pacific.

Simultaneously, China is engaged in a campaign of low-level coercion to assert control of disputed spaces in the region, particularly in the maritime domain. China is using a steady progression of small, incremental steps in the "gray zone" between peaceful relations and overt hostilities to secure its aims, while remaining below the threshold of armed conflict. Such activities can involve the coordination of multiple tools, including: political warfare, disinformation, use of A2/AD networks, subversion, and economic leverage.

During the last decade, China continued to emphasize capabilities for Taiwan contingencies. China has never renounced the use of military force against Taiwan, and continues to develop and deploy 
advanced military capabilities needed for a potential military campaign. PLA modernization is also strengthening its ability to operate farther from China's borders. For example, the PLA is reorganizing to improve its capability to conduct complex joint operations, and is also improving its command and control, training, personnel, and logistics systems. Key weapon systems deployed or in development, include: cruise and ballistic missile systems, modern fighter and bomber aircraft, aircraft carriers, modern ships and submarines, amphibious assault ships, surface-to-air missile systems, electronic warfare systems, direct-ascent, hit-to-kill anti-satellite missiles, and autonomous systems.

\section{China's Use of Economic Means to Advance Its Strategic Interests}

"Beijing is leveraging its economic
instrument of power in ways that can
undermine the autonomy of countries across
the region...easy money in the short term,
but these funds come with strings attached:
unsustainable debt, decreased transparency,
restrictions on market economies, and the
potential loss of control of natural
resources."

- $\quad$ Admiral Philip S. Davidson, Commander, U.S. Indo-Pacific Command, posture testimony before the Senate Armed Services Committee, February 12, 2019
China is using economic inducements and penalties, influence operations, and implied military threats to persuade other states to comply with its agenda. Although trade has benefitted both China and its trade partners, Chinese use of espionage and theft for economic advantage, as well as diversion of acquired technology to the military, remains a significant source of economic and national security risk to all of China's trading partners.

While investment often brings benefits

for recipient countries, including the United States, some of China's investments result in negative economic effects or costs to host country sovereignty. Chinese investment and project financing that bypasses regular market mechanisms results in lower standards and reduced opportunities for local companies and workers, and can result in significant debt accumulation. One-sided and opaque deals are inconsistent with the principles of a free and open Indo-Pacific, and are causing concern in the region. For example, in 2018, Bangladesh was forced to ban one of China's major state firms for attempted bribery, and in the same year, Maldives' finance minister stated that China was building infrastructure projects in the country at significantly inflated prices compared to what was previously agreed. Furthermore, a Chinese state-owned enterprise purchased operational control of Hambantota Port for 99 years, taking advantage of Sri Lanka's need for cash when its government faced daunting external debt repayment obligations.

The United States does not oppose China's investment activities as long as they respect sovereignty and the rule of law, use responsible financing practices, and operate in a transparent and economically sustainable manner. The United States, however, has serious concerns with China's potential to convert unsustainable debt burdens of recipient countries or sub-national groups into strategic and military access, including by taking possession of sovereign assets as collateral. China's coercive behavior is playing out globally, from the Middle East and Africa to Latin America and Europe. 
A lack of transparency also clouds China's activities in the polar regions. In 2018, China announced the inclusion of the region in One Belt One Road as the "Polar Silk Road" and emphasized its self-declared status as a "Near-Arctic State." China is also expanding its engagement and capabilities in the Antarctic, in particular by working to finalize a fifth research station, which will diversify its presence across the continent.

\section{RISK REDUCTION: ENGAGING CHINA}

One of the most far-reaching objectives of the National Defense Strategy is to set the military relationship between the United States and China on a long-term path of transparency and non-aggression. Pursuit of a constructive, results-oriented relationship between our two countries is an important part of U.S. strategy in the Indo-Pacific.

As the scope of China's military modernization and the reach of China's military activities expands, the need for strategic dialogue and safe and professional behavior consistent with international law is crucial. When China and the PLA operate in a manner consistent with international norms and standards, the risk of miscalculation and misunderstanding is reduced. Recognizing this, our bilateral military engagements with China, which include high-level visits, policy dialogues, and functional exchanges, are centered on building and reinforcing the procedures necessary to reduce risk and prevent and manage crises.

Through our military-to-military engagements, the Department of Defense will continue to encourage China to engage in behaviors that maintain peace and stability in the region and that support - rather than undermine - the rules-based international order. We will not accept policies or actions that threaten to undermine this order, which has benefited all countries in the region, including China. The United States is prepared to support China's choices to the extent that China promotes long-term peace and prosperity for all in the Indo-Pacific, and we remain open to cooperate where our interests align.

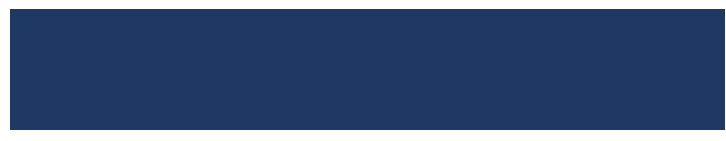

\section{THE BUILD ACT}

On October 5, 2018, President Trump signed into law the Better Utilization of Investments Leading to Development (BUILD) Act. The BUILD Act establishes a new U.S. International Development Finance Corporation. This legislation consolidates, modernizes, and reforms the U.S. Government's development finance capabilities. Backing from the U.S. Government can catalyze significant amounts of private capital into emerging markets. This model of mobilizing private investment is vital as the needs of developing countries are too great to meet with official government resources alone. The BUILD Act prioritizes low-income and lower middle-income countries, where the Development Finance Corporation's services will have the greatest impact. It more than doubles the U.S. development finance capacity from $\$ 29$ billion to $\$ 60$ billion. The new authorities and flexibility provided under the BUILD Act will give the United States greater agility to offer financially sound, transparent investment alternatives. 


\subsection{Russia as a Revitalized Malign Actor}

Russia's interest and influence in the region continue to increase through national outreach and military modernization - in both its conventional forces and strategic forces. Despite slow economic growth due to Western sanctions and decreasing oil prices, Russia continues to modernize its military and prioritize strategic capabilities - including its nuclear forces, A2/AD systems, and expanded training for long-range aviation - in an attempt to re-establish its presence in the Indo-Pacific region. Russia's operations and engagement throughout this region are consistent with its global influence activities, which seek to advance Moscow's strategic interests while undermining U.S. leadership and the rules-based international order.

Russia's efforts include using economic, diplomatic, and military means to achieve influence in the Indo-Pacific region. Moscow seeks to alleviate some of the effects of sanctions imposed, following its aggressive actions in Ukraine, by diplomatically appealing to select states in Asia and seeking economic opportunities for energy exports. Russia also seeks to increase defense and trade relations through arms sales in the region.

"For decades, the U.S. led the world in hypersonics research - and deliberately chose not to weaponize these systems. China and Russia have chosen differently. Our nation does not seek adversaries, but we will not ignore them either. We refuse to be bound by geography. Our new, space-based sensor layer will give us persistent, timely, global awareness."

Acting Secretary Shanahan, remarks on the 2019

Missile Defense Review, January 17, 2019
Russia is re-establishing its military presence in the Indo-Pacific by regularly flying bomber and reconnaissance missions in the Sea of Japan and conducting operations as far east as Alaska and the west coast of the continental United States. Russia has also intensified its diplomatic outreach in Southeast Asia, seeking to capitalize on U.S.-China tensions in order to present itself as a neutral "third partner." The Russian Navy has increased its operations and reach, with

the Russian Pacific Fleet deploying ships to support operations in the Middle East and Europe, and the Russian Baltic and Black Sea Fleets deploying to the Indo-Pacific. Russian ballistic missile and attack submarines remain active in the region, while Russia is also undertaking efforts to modernize its conventional forces and nuclear strike capabilities.

China and Russia collaborate across the diplomatic, economic, and security arenas. China has increased investment in Russia's economy and Russia is one of China's top sources for energy imports. In the security realm, China purchases advanced equipment such as Su-35 fighter aircraft and the S-400 surface-to-air missile system from Russia. The two countries participate in bilateral and multilateral military exercises together, including China's 2018 participation for the first time in Russia's annual strategic command and staff exercise, VOSTOK (East) 2018. China and Russia 
frequently jointly oppose U.S.-sponsored measures at the United Nations Security Council. Broadly, they share a preference for a multipolar world order in which the United States is weaker and less influential. Russia has Arctic interests linked to its significant Arctic Ocean coastline and the extraction of natural resources. This is witnessed by Russia's extended continental shelf claim, and an uptick in its military posture and investments to develop the region and the Northern Sea shipping route, including with Chinese involvement. However, an interest in reserving Arctic resources for littoral states may ultimately limit the extent and depth of Sino-Russian cooperation.

\subsection{The Democratic People's Republic of Korea as a Rogue State}

The Democratic People's Republic of Korea (DPRK or North Korea) will remain a security challenge for DoD, the global system, our allies and partners, and competitors, until we achieve the final, fully verifiable denuclearization as committed to by Chairman Kim Jong Un. Although a pathway to peace is open for a diplomatic resolution of North Korea's nuclear weapons program, other weapons of mass destruction, missile threats, and the security challenges North Korea presents are real and demand continued vigilance. North Korea's history as a serial proliferator, including conventional arms, nuclear technology, ballistic missiles, and chemical agents to countries, such as Iran and Syria, adds to our security concerns. Furthermore, the DPRK's continued human rights violations and abuse against its own people, including violations of individuals' freedom of expression, remain an issue of deep concern to the international community. The United States also continues to support Japan's position that North Korea must completely resolve the issue of Japanese abductees, and has raised this with North Korean authorities.

North Korea has developed an intercontinental ballistic missile intended to be capable of striking the continental United States with a nuclear or conventional payload. In 2017, North Korea conducted a series of increasingly complex ballistic missile launches eastward toward the United States. North Korea did so by overflying Japan with long-range ballistic missiles. Some tests were done at highly lofted trajectories designed to simulate flights at ranges that could reach the United States.

North Korea poses a conventional threat to U.S. allies, such as the Republic of Korea (ROK) and Japan. North Korea has long-range artillery arrayed against the ROK - particularly the Greater Seoul Metropolitan Area - capable of inflicting catastrophic damage on ROK civilians and large numbers of U.S. citizens. North Korea has demonstrated willingness to use lethal force to achieve its ends. In 2010, North Korea sank the ROK corvette CHEONAN and killed 46 sailors in an unprovoked attack. In 2010, it also shelled the ROK Yeonpyeong Island in the Yellow Sea, killing 2 civilians and 2 military personnel and wounding 22 more.

North Korea continues to circumvent international sanctions and the U.S.-led pressure campaign through diplomatic engagement, counter pressure against the sanctions regime, and direct sanctions 
evasion. Early in 2018, North Korea exceeded its sanctioned limit on refined petroleum imports through illicit ship-to-ship transfers. U.S. Indo-Pacific Command (USINDOPACOM) is working with allies and partners to enforce United Nations Security Council Resolutions (UNSCR) by disrupting illicit ship-to-ship transfers, often near or in Chinese territorial waters, and in the Yellow Sea. North Korea is also engaged in cross-border smuggling operations and cyber-enabled theft to generate revenue, while simultaneously circumventing United Nations Security Council prohibitions on coal exports.

The Trump Administration has pursued leader-level diplomacy with North Korea for the first time, which has highlighted unique opportunities for a brighter future for North Korea. Until North Korea clearly and unambiguously makes the strategic decision to take steps to denuclearize, the United States will continue to enforce all applicable domestic and international sanctions, and DoD will remain ready to deter, and if necessary, defeat any threats to the United States, the ROK, Japan, or our other allies and partners.

\subsection{Prevalence of Transnational Challenges}

The Indo-Pacific region continues to experience a myriad of security challenges from a range of transnational threats, including: terrorism; illicit arms; drug, human, and wildlife trafficking; and piracy, as well as dangerous pathogens, weapons proliferation, and natural disasters. Multiple terrorist organizations, including the Islamic State of Iraq and Syria (ISIS), operate in countries throughout the region. The heavily-traveled Indo-Pacific sea lanes are targets for pirates seeking to steal goods or hold ships and crews for ransom. Illegal, unreported, and unregulated fishing further challenges regional peace and prosperity. A region already prone to earthquakes and volcanoes as part of the Pacific Ring of Fire, the Indo-Pacific region suffers regularly from natural disasters including monsoons, hurricanes, and floods to earthquakes and volcanic activity, as well as the negative consequences of climate change.

Another issue of concern is weak and illiberal governance in countries. Governments that are not responsive to the will of their people are more susceptible to malign external influence. For example, democratic backsliding in Cambodia has taken place since 2017, when the ruling party banned independent media and dissolved the main opposition party. Additionally, we remain concerned about reports that China is seeking to establish bases or a military presence on its coast, a development that would challenge regional security and signal a clear shift in Cambodia's foreign policy orientation. In Burma, the lack of a robust democracy has set conditions for human rights atrocities committed by Burmese security forces in northern Rakhine State since August 2017, and has created regional instability, with more than one million Rohingya refugees currently in Bangladesh. 
The United States is encouraged by positive indicators within South and Southeast Asia that democratic institutions are on an upward trajectory and steadily improving transparency, responsibility, and democratic values. These indicators include freedom of the press, civilian control of the military, and free and fair elections in countries such as the Philippines, Malaysia, and Indonesia, each of which experienced autocratic rule in the past.

In South Asia, Sri Lanka and the Maldives are also on a positive trajectory. In Sri Lanka, after 25 years of conflict, the government has transitioned to a constitutional, multiparty republic with a freelyelected President and Parliament. The political system was challenged with a constitutional dispute in late 2018. Ultimately, however, all parties respected the Supreme Court ruling that returned democratic processes and norms, and the military remained uninvolved throughout the dispute. The Republic of Maldives' historic election in 2018 - with 90 percent of the eligible population voting ushered in the new president, who has outlined an agenda for sweeping reforms to promote free media, an independent judiciary, and transparent public financial management. 


\section{US NATIONAL INTERESTS AND DEFENSE STRATEGY}

\subsection{U.S. National Interests}

2017 U.S. National Security Strategy is based upon the view that peace, security, and prosperity depend on strong, sovereign nations that respect their citizens at home and cooperate to

L advance peace abroad. It is grounded in the belief that U.S. leadership in promoting these widely held principles is a lasting force for good in the world. As such, DoD is working to support enduring U.S. national interests, as articulated in the National Security Strategy:

1. Protect the American people, the homeland, and the American way of life;

2. Promote American prosperity through fair and reciprocal economic relationships to address trade imbalances;

3. Preserve peace through strength by rebuilding our military so that it remains preeminent, and rely on allies and partners to shoulder a fair share of the burden of responsibility to protect against common threats; and, 
4. Advance American influence by competing and leading in multilateral organizations so that American interests and principles are protected.

While these interests are global in nature, they assume a heightened significance in a region as strategically and economically consequential as the Indo-Pacific.

\subsection{U.S. National Defense Strategy}

The 2018 National Defense Strategy guides the Department of Defense to support the National Security Strategy in order to:

1. Defend the homeland;

2. Remain the preeminent military power in the world;

3. Ensure the balances of power in key regions remain in our favor; and

4. Advance an international order that is most conducive to our security and prosperity.

Both the National Security Strategy and the National Defense Strategy affirm the Indo-Pacific as critical for America's continued stability, security, and prosperity. The United States seeks to help build an IndoPacific where sovereignty and territorial integrity are safeguarded, the promise of freedom is fulfilled, and prosperity prevails for all. We stand ready to cooperate with all nations to achieve this vision.

The National Defense Strategy informs how we work with our neighbors in the Indo-Pacific and beyond, to address key challenges in the region. The core diagnosis of the National Defense Strategy is that DoD's military advantage vis-à-vis China and Russia is eroding and, if inadequately addressed, it will undermine our ability to deter aggression and coercion. A negative shift in the regional balance of power could encourage competitors to challenge and subvert the free and open order that supports prosperity and security for the United States and its allies and partners. To address this challenge, DoD is developing a more lethal, resilient, and rapidly innovating Joint Force, and is increasing collaboration with a robust constellation of allies and partners.

The challenges we face in the Indo-Pacific extend beyond what any single country can address alone. The Department seeks to cooperate with like-minded allies and partners to address common challenges. The United States acknowledges that allies and partners are a force multiplier for peace and interoperability, representing a durable, asymmetric, and unparalleled advantage that no competitor or rival can match. We seek to provide the structure that allows our respective militaries to work together - leveraging our complementary forces, unique perspectives, regional relationships, and information capabilities. Taking deliberate steps in these areas will allow us to improve our collective ability to compete, deter, and if necessary, fight and win together. 


\section{SUSTAINING US. INFLUENCE TO ACHIEVEREGIONAL OBJECTIVES}

he National Defense Strategy directs the Department to increase lethality, to strengthen alliances, and to expand the competitive space. In the context of the Department's Indo-Pacific

Strategy, this translates into the pursuit of Preparedness, Partnerships, and Promoting a Networked Region.

\subsection{Line of Effort 1: Preparedness}

The National Defense Strategy directs the Department to employ its resources in ways that enhance the lethality, resilience, agility, and readiness of the Joint Force. This resourcing must span near-term force employment activities and longer-term investments to modernize and redesign the U.S. military. The Department is developing innovative capabilities and operating concepts to address specific operational problems. This also involves identifying new, asymmetric ways to upgrade and employ legacy systems. Experimentation and exercises to test evolving warfighting concepts and capabilities help create a virtuous cycle that spurs additional ideas and innovations. Many of these experiments 
and exercises are being conducted alongside allies and partners to ensure we can test and improve interoperability for joint and combined operations.

The National Defense Strategy implicitly acknowledges the most stressing potential scenarios will occur along our competitors' peripheries. If our competitors decide to advance their interests through force, they are likely to enjoy a local military advantage at the onset of conflict. In a fait accompli scenario, competitors would seek to employ their capabilities quickly to achieve limited objectives and forestall a response from the United States, and its allies and partners. DoD initiatives on force employment, crisis response, force and concept development, and collaboration with allies and partners are aimed to help address this critical challenge.
“The 2018 National Defense Strategy's unified framework enables a potent combination of teamwork, resources, and an unmatched network of allies and partners stepping up to shoulder their share of the burden for international security. The National Defense Strategy also fosters alignment within the Department, the Interagency, industry, and Congress."

Acting Secretary of Defense Shanahan, testimony to the House Armed Services Committee, March 26, 2019

The National Defense Strategy directs the Department to posture ready, combat-credible forces forward - alongside allies and partners - and, if necessary, to fight and win. This approach intentionally presents competitors with a dilemma by ensuring they cannot quickly, cheaply, or easily advance their aims through military force. Competitors are compelled to advance their interests through other, more benign means - which are often subject to internationally recognized rules or widelyaccepted state practices.

The Department is undertaking a range of efforts to enhance Joint Force preparedness for the most pressing scenarios. Examples of DoD initiatives include:

"We are adapting to fight against near-peer competitors. Our armed forces are learning to expect to be contested throughout the fight...We are changing our mindset, working to regain our advantages, and playing to our strengths. Alliances and partnerships are at the heart of this competitive effort."

Assistant Secretary of Defense for Indo-Pacific Security Affairs, Randall G. Schriver, speech at the Elliot School of International Affairs, February 7, 2019

- Investments in Advanced Training Facilities at the Joint Pacific Alaska Range Complex to present a more a realistic and representative training environment;

- Investments in unit and depot maintenance across Air Force and Naval Aviation to achieve an 80 percent fighter readiness goal by the end of Fiscal Year (FY) 2019; and,

- Investments in advanced missile defense systems interoperable with allied systems in Japan and Australia. 
The Department is also modernizing the force to meet the demands of high-end competition. Illustrative examples of key investments include:

- Acceleration of the development and forward presence of U.S. land forces' Multi-Domain Task Force, utilizing Security Force Assistance Brigades to build partner capacity and strengthen multinational teams, and expanding Pacific Pathways to deepen relationships with U.S. allies and partners;

- Strategic deterrence enhancements associated with investments in the new Columbia-class ballistic missile submarine;

- Purchase of 110 4th- and 5th-generation aircraft which will result in both capability and capacity improvements;

- Purchase of approximately 400 Advanced Medium-Range Air-to-Air Missiles;

- Purchase of more than 400 Joint Air-Surface Missiles - Extended Range;

- Investments in two Unmanned Surface Vehicles, additional Long Range Anti-Ship Missiles, and additional Maritime Strike Tactical Tomahawks;

- Increased capacity in Anti-Surface Warfare, Anti-Submarine Warfare, and Ballistic Missile Defense (BMD) by purchasing 10 more destroyers within the FY 2020-2024 Future Years Defense Program;

- Investment in resources to support offensive and defensive cyberspace operations; and,

- Efforts to unify, focus, and accelerate the development of space doctrine, capabilities, and expertise to outpace future threats, institutionalize advocacy of space priorities, and further build space warfighting culture.

\section{Current Posture in the Indo-Pacific}

Defense posture is a visible manifestation of U.S. national interests and priorities abroad, and makes up the network of U.S. forces and capabilities that are forward-deployed in the region, as well as the interconnected bases, infrastructure, installations, and international agreements that support both dayto-day and wartime employment of the force.

In the region, USINDOPACOM currently has more than 2,000 aircraft; 200 ships and submarines; and more than 370,000 Soldiers, Sailors, Marines, Airmen, DoD civilians, and contractors assigned within its area of responsibility. The largest concentration of forces in the region are in Japan and the ROK. A sizable contingent of forces (more than 5,000 on a day-to-day basis) are also based in the U.S. territory of Guam, which serves as a strategic hub supporting crucial operations and logistics for all U.S. forces operating in the Indo-Pacific region. Other allies and partners that routinely host U.S. forces on a smaller scale include the Philippines, Australia, Singapore, and the United Kingdom through the island of Diego Garcia. 


\section{Future Posture in the Indo-Pacific}

To achieve our strategic objectives in the Indo-Pacific, we seek to evolve our posture and balance key capabilities across South Asia, Southeast Asia, and Oceania to have a more dynamic and distributed presence and access locations across the region. For example, as announced by Vice President Pence on November 16, 2018, the United States seeks to partner with Papua New Guinea and Australia on their joint initiative at Lombrum Naval Base on Manus Island.

In order to overcome the tyranny of distance, posture that supports and enables inter- and intratheater logistics must be flexible and resilient, and the pre-positioning of equipment is critical. Specifically, we are exploring expeditionary capabilities; dynamic basing of maritime and air forces; special operations forces capable of irregular and unconventional warfare; anti-submarine capabilities; cyber and space teams equipped for multi-domain operations; and, unique intelligence, surveillance, and reconnaissance (ISR) capabilities - among other investments. From leveraging existing access in the Compact States, to pursuing co-development with our most capable allies and partners, we will continue to forward-station leading edge technologies, such as 5th generation fighters in the IndoPacific.

DoD is also developing new operating concepts to increase our lethality, agility, and resilience that will be further implemented through our evolving posture. For example, as part of the Multi-Domain Operations concept, the U.S. Army will test MultiDomain Task Forces intended to create temporary windows of superiority across multiple domains, and allow the Joint Force "DoD's participation in combined military exercises has increased by seventeen percent in the last two years, and our Foreign Military Sales have increased by more than sixty-five percent in the last three years."

Acting Secretary of Defense Shanahan, testimony to the House Armed Services Committee, March 26, 2019 to seize, retain, and exploit the initiative. The U.S. Army will test the Multi-Domain Task Forces through the Pacific Pathways program to determine the right capability mix and locations. Furthermore, the Expeditionary Advanced Base Operations is an emerging U.S. Navy and Marine Corps operating concept to provide resilience and support to maritime operations inside contested environments. It is intended to deny adversary freedom of action; control key maritime terrain; and support Joint Force air and maritime requirements by operating from austere locations at a tempo that complicates adversary targeting.

In addition, DoD will continue to ensure a force posture that enables the United States to undertake a spectrum of missions including security cooperation, building partner capacity, collaboration on transnational threats, and joint and combined training. 


\subsection{Line of Effort 2: Partnerships}

U.S. engagement in the Indo-Pacific is rooted in our long-standing security alliances - the bedrock on which our strategy rests. Mutually beneficial alliances and partnerships are crucial to our strategy, providing a durable, asymmetric strategic advantage that no competitor or rival can match.

Expanding our interoperability with allies and partners will ensure that our respective defense enterprises can work together effectively during day-to-day competition, crisis, and conflict. Through focused security cooperation, information-

"Our network of allies and partners is a force multiplier for peace and interoperability."

\section{National Defense Strategy} sharing agreements, and regular exercises, we are connecting intent, resources, and outcomes and building closer relationships between our militaries and economies. Increasing interoperability also involves ensuring our military hardware and software are able to integrate more easily with those of our closest allies and partners, offering financing and sales of cutting-edge U.S. defense equipment to security partners, and opening up the aperture of U.S. professional military education to more IndoPacific military officers.

\section{BURDEN SHARING}

The National Security Strategy calls on the United States to pursue cooperation and reciprocity together with our allies, partners, and aspiring partners.

Cooperation means sharing responsibilities and burdens. The United States expects our allies and partners to shoulder a fair share of the burden of responsibility to protect against common threats. When we pool resources and share responsibility for our common defense, our security burden becomes lighter and more cost-effective.
To this end, we have strengthened our alliances with Japan, South Korea, Australia, the Philippines, and Thailand. These alliances are indispensable to peace and security in the region and our investments in them will continue to pay dividends for the United States and the world, far into the future. We have also taken steps to expand partnerships with Singapore, Taiwan, New Zealand, and Mongolia. Within South Asia, we are working to operationalize our Major Defense Partnership with India, while pursuing emerging partnerships with Sri Lanka, the Maldives, Bangladesh, and Nepal. We are also continuing to strengthen security relationships with partners in Southeast Asia, including Vietnam, Indonesia, and Malaysia, and sustaining engagements with Brunei, Laos, and Cambodia. In the Pacific Islands, we are enhancing our engagement to preserve a free and open IndoPacific, maintain access, and promote our status as a security partner of choice. Efforts to maintain a free and open Indo-Pacific have also brought us closer to key allies, including the United Kingdom, France, and Canada, each with their own Pacific identities. 


\section{Modernizing Alliances}

\section{JAPAN}

The U.S.-Japan Alliance is the cornerstone of peace and prosperity in the Indo-Pacific, with the United States remaining steadfast in its commitment to defend Japan and its administered territories. As the security dynamic in the Indo-Pacific evolves, however, it is imperative that the U.S.-Japan Alliance

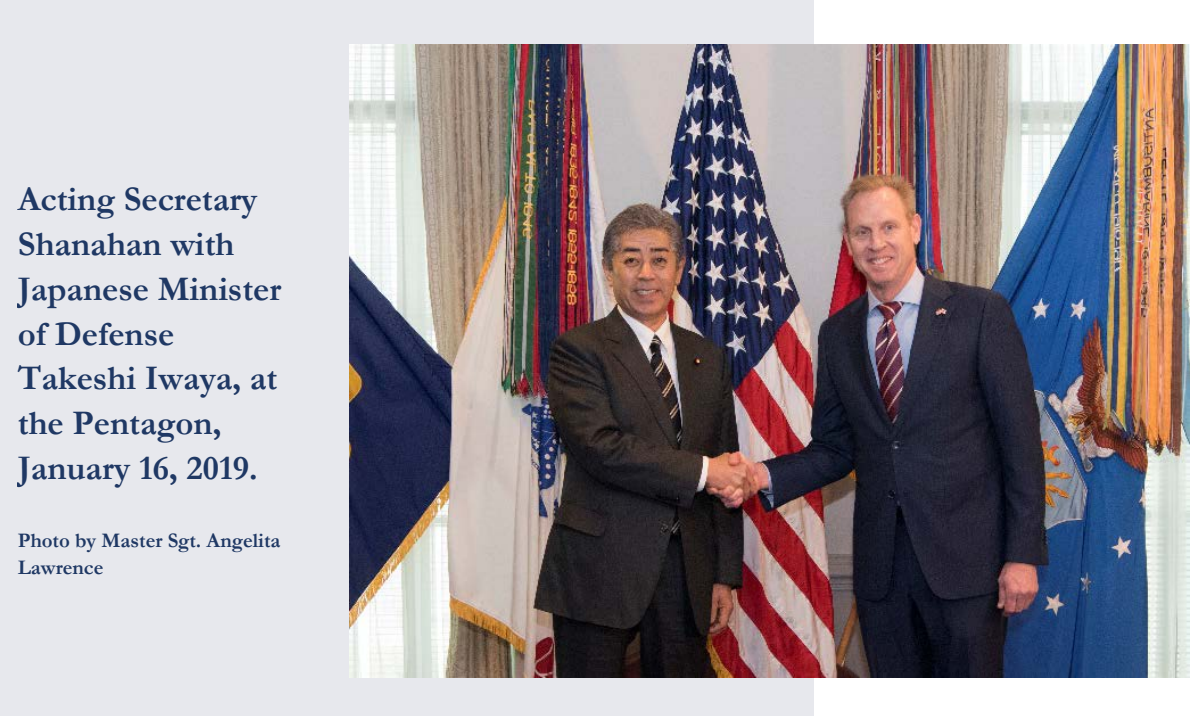
adapt to meet the challenges that threaten our security and shared values. Whether countering North Korea's rogue behavior, or long-term strategic competition with China and Russia, we must pursue concrete objectives that preserve the alliance as our asymmetric advantage.

The National Defense Strategy clearly articulates that the Department will prioritize and strengthen our alliances, identifying the U.S.Japan Alliance as a critical relationship. Japan's 2018 National Defense Program Guidelines echoes a similar message, reinforcing the fundamental fact that the security interests of both the United States and Japan are closely intertwined. Given the urgency to address new threats, trends, and technologies, we have already seen progress in operational cooperation, mutual asset protection, and bilateral planning. Maintaining the technological advantage the alliance needs to fight and win against our adversaries is also a top-tier priority, with the Department continuing to streamline Foreign Military Sales (FMS) to Japan and other allies, pursue codevelopment opportunities, and deepen cooperation in the cyber

\section{FOREIGN MILITARY SALES}

The National Security and National Defense Strategies have elevated FMS as a tool of first resort in strengthening alliances and attracting new partners. Conventional Arms Transfer Policy and Security Cooperation reforms have focused our ability to improve the efficiency and effectiveness of FMS. We have been successful in reducing costs, improving processing times, and minimizing policy hurdles to make technology more available to a larger group of partners. and space domains. 


\section{POSTURE: JAPAN}

U.S. forces in Japan are an essential component of our posture in the region. To meet shared threats, advance common interests, and fulfill our obligations under the U.S.-Japan Treaty of Mutual Cooperation and Security - a key enabler for maintaining a free and open Indo-Pacific region - the Department remains steadfast in its commitment to deploy our most capable and advanced forces to

\section{GUAM AND THE COMMONWEALTH OF THE NORTHERN MARIANA ISLANDS (CNMI)}

The Department is modernizing its force posture in Guam, in keeping with Guam's position as the westernmost territory of the United States and a strategic hub for our joint military presence in the region. We are establishing a Marine Air Ground Task Force of 5,000 U.S. Marines in Guam starting in the first half of the 2020s as a central feature of the U.S.-Japan realignment plan. In Guam, we have some of the most significant ammunition and fuel storage capabilities in the IndoPacific. The addition of rotational maritime lift in Guam will increase the reach of our combat power in the Western Pacific. At Anderson Air Force Base, we have established an active Army Missile Defense capability in response to increasing threats, and maintain a continuous bomber presence and ISR capability. In the CNMI we have air, surface, and subsurface training capabilities and we are taking steps to ensure we will have ready joint forces and opportunities for increased multilateral training.

The Government of Japan has already provided more than $\$ 2$ billion of a $\$ 3.1$ billion commitment for construction of facilities for the U.S. Marine Corps realignment. The U.S. Government will fund the balance of construction, estimated at $\$ 8.6$ billion, and is working toward an outcome that enhances our Indo-Pacific posture, bolsters our security commitments in the region, and directly benefits Guam.
Japan. The Government of Japan contributes financially to the stationing of U.S. forces in Japan through a Special Measures Agreement. This strategic contribution directly supports the operational readiness of U.S. forces in Japan.

The Department assigns approximately 54,000 military personnel to Japan, in the U.S. Navy's Seventh Fleet, U.S. Marine Corps' III Marine Expeditionary Force, 3 Air Force wings, and smaller U.S. Army and Special Operations units. Some of the more advanced capabilities stationed in Japan include the F-35, MV and CV-22, and the USS RONALD REAGAN, our only forward deployed aircraft carrier. BMD assets are also tightly woven into our force posture in Japan, including AEGIS Destroyers, sophisticated BMD radar systems, and a PATRIOT firing unit to counter the ballistic missile threat. Enhancing operational cooperation between the U.S. forces and Japan Self Defense Forces (JSDF) is also a priority, as outlined in the 2015 Guidelines for U.S.-Japan Defense Cooperation. Bilateral presence operations throughout the IndoPacific region, mutual asset 
protection missions, and bilateral exercises are just a few areas of operational cooperation that U.S. forces and the JSDF collaborate on to advance our shared objectives.

The realignment of U.S. forces in Japan contributes to a regional force posture that is geographically distributed, operationally resilient, and politically sustainable. We have already made substantial progress on this initiative. Examples include the movement of the U.S. Navy's Carrier Air Wing Five to Marine Corps Air Station Iwakuni, the stationing of JSDF units on U.S. Air Force and Army bases, and the return of more than 10,000 acres of land in Okinawa to the Government of Japan. Future steps include the completion of the Futenma Replacement Facility and the return of U.S. Marine Corps Air Station Futenma, as well as the consolidation of our remaining bases and the return of additional land in Okinawa, Japan.

\section{REPUBLIC OF KOREA}

The United States remains steadfast in its commitment to the defense of the Republic of Korea (ROK). The U.S.ROK Alliance is the linchpin of peace and prosperity in Northeast Asia, as well as the Korean Peninsula.

The Department is continuing its work with the ROK Ministry of National Defense to transition wartime operational control for Combined Forces Command (CFC) from a U.S. Commander to a ROK

"The alliance between South Korean and American forces is ironclad - forged in blood, shaped over 65 years of combined military operations and training, and hardened by the crucible of war. Shared sacrifice and mutually agreed principles underpin our alliance and ensure it endures the winds of change."

Commander of U.S. Forces Korea, General Robert B. Abrams, testimony to the Senate Armed Services Committee, February 12, 2019

Commander. To achieve this, the DoD

and the ROK Ministry of National Defense are investing in critical military capabilities to ensure our combined readiness to meet any threat to the alliance. The United States and the ROK are also working to enhance alliance capabilities in the fields of space, cyberspace, and missile defense, along with efforts to counter weapons of mass destruction.

Together, the United States and the ROK are constantly improving our ISR capacity; developing a robust, tiered BMD; fielding appropriate command and control assets; acquiring necessary inventories of critical munitions; and enhancing the tools to prevent, deter, and respond to cyber attacks.

The United States and the ROK continue combined training through command post exercises, as well as field training exercises to ensure the readiness and combat proficiency of combined forces on the Peninsula and in the region. The Department is also working to revitalize the United Nations Command, which contributes to peace and stability on the Korean Peninsula through oversight and maintenance of the 1953 Armistice Agreement. 


\section{POSTURE: REPUBLIC OF KOREA}

The U.S-ROK combined force - unique among bilateral U.S. military relationships - is a robust deterrent to aggression on the Korean Peninsula. As we sustain readiness for any conflict, the United States and the ROK also remain committed to the final, fully verified denuclearization of North Korea and enduring peace on the Korean Peninsula.

The Department has three unique commands on the Korean Peninsula: U.S. Forces Korea (USFK), the CFC, and the United Nations Command. The ROK hosts 28,500 U.S. service members and their families to units including the U.S. Eighth Army and 2nd Infantry Division, Seventh Air Force, U.S. Marine Corps Forces Korea, U.S. Special Operations Command-Korea,

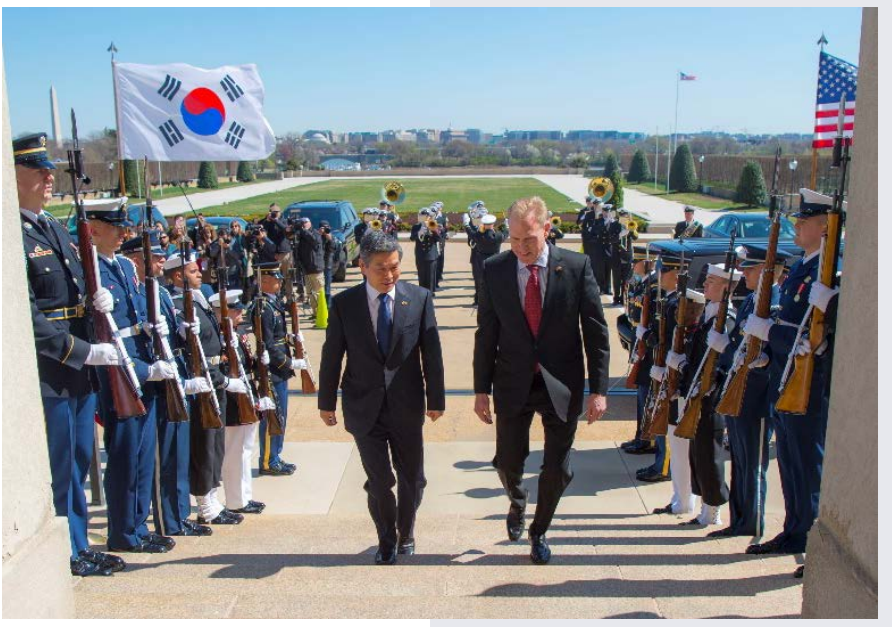
Acting Secretary of Defense Shanahan hosts the South Korean Minister of National Defense Jeong Kyeong-doo at the Pentagon, April 1, 2019. and Commander, Naval Forces Korea. Advanced capabilities stationed in South Korea include two fighter wings of F-16 and A-10 aircraft; a major U.S. Army prepositioned stockpile; a combat aviation brigade; a field artillery brigade; advanced ISR units; and a headquarters for the U.S. Army Corps of Engineers. The ROK continues to invest more in its defense over the past 15 years than it did in decades

"The force is sufficiently postured to deter aggression and defeat any adversary, if necessary. We continue to train at echelon to maintain the readiness required to translate a strong military posture into decisive victory on short notice."

General Abrams, testimony to the Senate Armed Services Committee, February 12, 2019 before, spending over 2 percent of its gross domestic product on defense and increasing foreign military procurements from the United States, such as the KF-16 and PATRIOT battery upgrades, AH-64E Apaches, the F-15K, RQ-4 Global Hawk variants, and the F-35A Joint Strike Fighter. Seoul also has future procurement plans for the P-8, advanced munitions, upgrades to PAC-3 missiles, and F-16 fighters - all of which will increase interoperability with the United States.

Significant improvements in U.S. Force posture during 2018 include adding essential munitions, BMD systems, and pre-positioned wartime stocks. The United States continues to work with the ROK to create an interoperable BMD architecture that addresses the ballistic missile threat from North Korea. In 2017, the United States deployed a Terminal High Altitude Area Defense battery to the ROK. 
The United States and the ROK have agreed to a 10th Special Measures Agreement that will enable the ROK to help offset the cost of stationing U.S. forces on the Korean Peninsula. The Special Measures Agreement will ensure essential readiness related personnel and activities, including the contributions of 9,000 South Korean national employees of USFK serving in crucial roles of public safety, health care, emergency response, and quality-of-life delivery operations.

Our joint efforts in military construction and modernization ensures our forces are postured, prepared, and properly set for the future. The Land Partnership Plan and the associated Yongsan Relocation Plan are bilateral agreements that provide the foundation for streamlining USFK's footprint while returning facilities and valuable land to the ROK Government for future development. In 2018, USFK and United Nations Command Headquarters relocated both commands from U.S. Army Garrison Yongsan to U.S. Army Garrison Humphreys in Pyeongtaek, joining U.S. Eighth Army and 2nd Infantry Division in new state-of-the-art facilities on the largest DoD facility outside of the continental United States. By consolidating capability in Pyeongtaek, on facilities built mostly with ROK funds, we maximize our ability to uphold U.S. security commitments, return large portions of downtown Seoul to the Korean people for economic development, and improve the quality of life for our Service members and their families. Since 2003, USFK has returned 49 sites to the ROK while simultaneously moving the majority of our forces and families away from the demilitarized zone and closer to major air and sea ports.

\section{AUSTRALIA}

U.S. and Australian forces have shared the battlefield in every major conflict since the First World War and celebrated their "First Hundred Years of Mateship" in 2018. For more than a century, we have conducted joint and coalition operations, training and exercises, intelligence cooperation, and capability development. The United States and Australia share a commitment to building on the interoperability of our armed forces, collaborating to ensure the security of the Indo-Pacific region into the future, and seeking innovative ways to adapt to new threats.

Australia is providing forces in Iraq for the counter-ISIS fight as trainers, force protection, and advisors. Australia's significant commitment to a stable and secure Afghanistan is also helping modernize our alliance through its contribution to the North Atlantic Treaty Organization (NATO)led Resolute Support Mission to train, advise, and assist the Afghan National Defense and Security Forces. Australia is also a key contributor to the UNSCR enforcement operations to bring North Korea into compliance with its international obligations and serves as a significant partner to the Philippines in building counter-terrorism capacity.

Both the United States and Australia are strengthening security in the Indo-Pacific through more deliberate coordination of the policies and priorities underlying regional engagements by promoting interoperability to address new threats, increasing focus on the Pacific Islands, and leveraging the U.S.Australia force posture initiatives and the unique exercising and training opportunities created in the process. 
The Department is also partnering with Australia in cyber, space, and defense science and technology domains. Together, we are building upon our long-established defense intelligence partnership through the regular exchange of information and assessments - which strengthens our situational awareness and capability and enhances our ability to operate together in support of regional stability and the rules-based international order. The United States and Australia intend to explore new models of development, acquisition, and sustainment and continue to transform our defense organizations and processes to meet new challenges.

\section{POSTURE: AUSTRALIA}

In 2014, the United States and Australia signed the Force Posture Agreement, a 25-year plus agreement governing our Force Posture Initiatives and providing our forces more opportunities to work bilaterally, and in trilateral and regional activities, in areas including maritime capacity building and humanitarian assistance and disaster relief (HA/DR).

There are two Force Posture Initiatives in northern Australia: (1) the Enhanced Air Cooperation, improving interoperability through longer duration, more sophisticated training; and (2) Marine Rotational Forces-Darwin, an annual rotational presence of up to 2,500 U.S. Marines. The Force Posture Initiatives promote a combined capability to respond to crises and contingencies, strengthen interoperability, and further engagement with regional partners.

In 2018, the U.S. Marine Rotational Forces-Darwin completed its seventh rotation, training with forces from Australia and 12 other regional countries and deploying as part of Australia's Indo-Pacific Endeavor - a flotilla that conducted security cooperation activities in Southeast Asia and the

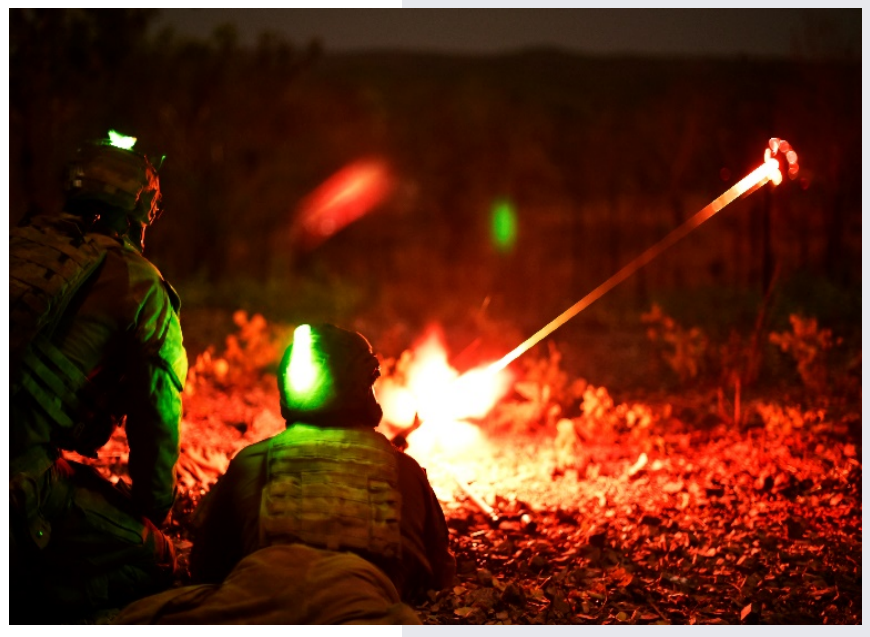
Australian Defence Force members with Charlie Company, 5th Royal Australian Regiment, fire squad automatic weapons during Marine Rotational Force - Darwin's Exercise KOOLENDONG at Mount Bundey Training Area, Australia, August 22, 2018.

Photo by the U.S. Department of Defense Pacific Islands.

In 2019, the Marine

Rotational Forces-Darwin is expected to grow to 2,500 U.S. Marines. Enhanced Aircraft Cooperation will deepen as well in 2019, with a robust set of activities planned, and deployment of new capabilities for these engagements. 


\section{THE PHILIPPINES}

The 1951 U.S.-Philippines Mutual Defense Treaty provides the foundation for our bilateral security cooperation, along with the 1998 Visiting Forces Agreement, and 2014 Enhanced Defense

The United States officially returned the Bells of

Balangiga to the

Philippines, December 11, 2018. (Left to right)

Philippines' Defense Secretary Delfin Lorenzana, the Executive Secretary of the Philippines Salvador Medialdea, U.S. Deputy Assistant Secretary of Defense Joseph H. Felter, and U.S. Ambassador to the Philippines Sung Kim.

Photo by the U.S. Department of State

Cooperation

Agreement (EDCA). These foundational agreements and our longstanding history enabled U.S. forces to support the Philippines during its battles against ISIS-aligned extremists that captured the city of Marawi in 2017. U.S. Special Operations Forces advisors remain in the country to date and provide our continued support to the Armed Forces of the Philippines.

We have 280 bilateral defense activities planned with the Philippines in 2019, and the Philippines hosts the most bilateral exercises in the USINDOPACOM area of responsibility. This robust annual cooperation ensures our forces maintain a sufficient level of interoperability to respond in times of crisis.

The Department is partnering with the Armed Forces of the Philippines in its 15-year modernization plan to upgrade its capabilities for territorial defense. The main areas of emphasis are maritime security, ISR, and aviation. The United States and the Philippines are also partnering on reconstituting counterterrorism forces following the Marawi siege.

In December 2018, then-Secretary James

"In returning the Bells of Balangiga to our ally and friend - the Philippines - we pick up our generation's responsibility to deepen the respect between our two peoples."

\footnotetext{
Then-Secretary of Defense Mattis, F.E. Warren Air Force Base, Wyoming, November 15, 2018
} Mattis, with authority delegated by the President, returned the Bells of Balangiga to the Philippines. The Bells were seized during the U.S.Philippine War in 1901 and are venerated as religious artifacts by the people of the Philippines. In returning the Bells of Balangiga to the people of the Philippines, the United States cements the tight bond between our two countries and peoples, which is based on respect and shared sacrifice.

In March 2016, the United States and the Philippines began to implement the EDCA to give our forces access to key facilities and allow our militaries to work even more closely together. As part of this implementation, we are supporting the modernization of the Armed Forces of the Philippines 
and strengthening mutual defense. There are five EDCA Agreed Locations arrayed throughout the archipelago: Antonio Bautista Air Base, Basa Air Base, Fort Magsaysay Military Reservation, Lumbia Air Base, and Mactan Benito Ebuen Air Base. The first projects under the agreement were completed in 2018 and an additional 12 projects have been approved for implementation for 2019 and 2020 . These investments provide force posture enhancements, improve our future readiness, and improve the operational flexibility of the alliance during contingencies.

In March 2019, Secretary of State Pompeo reaffirmed our commitment to the Mutual Defense Treaty, providing assurances that, "as the South China Sea is part of the Pacific, any armed attack on Philippine forces, aircraft, or public vessels in the South China Sea will trigger mutual defense obligations under Article IV of our Mutual Defense Treaty."

The United States and the Philippines continue to find new ways to meet our shared goals. For example, at the invitation of the Government of the Philippines, we concluded a bilateral air exercise at Basa Air Base that incorporated fighter aircraft of the Armed Forces of the Philippines and the U.S. Air Force.

\section{THAILAND}

The United States and Thailand established relations in 1818 and shortly thereafter, Thailand became an ally after signing the Treaty of Amity and Commerce in 1833. Our deep and longstanding militaryto-military ties with Thailand were formalized in 1954 with the signing of the Southeast Asia Collective Defense Treaty (Manila Pact), and in 2003 we reaffirmed our commitment to Thailand by designating it a major non-NATO ally. The 2014

\section{MILITARY EXERCISES IN THE INDO-PACIFIC}

The United States holds some 90 named military exercises in the Indo-Pacific each year, with the vast majority of these exercises being conducted jointly or combined with our allies and partners. These forces and exercises cooperate with militaries across the region in a range of activities from real time HA/DR to the full spectrum of conventional warfare skills to deter our adversaries. military coup created significant challenges. As Thailand continues to take steps toward democracy, DoD looks forward to strengthening our longstanding defense ties.

Together we are advancing shared goals of enhancing regional security; confronting public health challenges; countering transnational crime; combating trafficking in persons, wildlife, and narcotics; and assisting refugees and displaced persons. We currently hold more than 130 military-tomilitary engagements each year, including the Indo-Pacific's largest military exercise, COBRA GOLD.

As a U.S. ally that is both central to ASEAN and positioned between South Asia and Southeast Asia, Thailand plays a key geostrategic role in the Indo-Pacific region. The access provided to Utapao Royal Thai Naval Air Station and the associated deep-water port at Sattahip is a critical enabler for U.S. force 
projection. Utapao supports logistics activities and HA/DR operations such as support to efforts surrounding the 2015 earthquake in Nepal.

The United States currently enjoys information sharing with Thailand enabled by a General Security of Military Information Agreement, communications security via a Communications and Information Security Memorandum of Agreement, and logistics sharing via an Acquisition and Cross-Servicing Agreement. Our future efforts in Thailand will focus on maintaining and enhancing access at cooperative security locations, expanding the scope and complexity of our current exercises, and supporting the Royal Thai Armed Forces' modernization efforts, most notably the Royal Thai Army's intent to update its Brigade Combat Team construct centered on the U.S. Stryker vehicle.

\section{Strengthening Partnerships}

As democracies in the Indo-Pacific, Singapore, Taiwan, New Zealand, and Mongolia are reliable, capable, and natural partners of the United States. All four countries contribute to U.S. missions around the world and are actively taking steps to uphold a free and open international order. The strength of these relationships is what we hope to replicate in our new and burgeoning relationships in the Indo-Pacific.

\section{SINGAPORE}

Singapore remains a steadfast partner in Southeast Asia with a strong commitment to promote regional and global stability. Our long-standing defense relationship is underpinned by the 1990 Memorandum of Understanding, the 2005 Strategic Framework Agreement, and the 2015 U.S.Singapore Enhanced Defense Cooperation Agreement. In the 2005 Strategic Framework Agreement, the United States designated Singapore a "Major Security Cooperation Partner." Singapore provides access to U.S. Navy ships, as well as U.S. military aircraft, including most recently littoral combat ships and P-8 Poseidon aircraft, whose presence has contributed to the security and stability of Southeast Asia, and continues to ensure a free and open Indo-Pacific.

The Department has long hosted training detachments of fighter aircraft from Singapore to train alongside the U.S. Air Force in the United States, which helps to further deepen our security ties and boost interoperability. Singapore annually sends approximately 1,000 personnel to training and education courses in the United States, representing the largest training presence in the United States from any foreign military.

Singapore was the first and only Asian country to contribute assets and personnel to the Global Coalition to Defeat ISIS, and has participated in Operation Gallant Phoenix since May 2017. Singapore has commanded Combined Task Force 151 in the Gulf of Aden five times. 


\section{TAIWAN}

The United States has a vital interest in upholding the rules-based international order, which includes a strong, prosperous, and democratic Taiwan. The United States is pursuing a strong partnership with Taiwan and will faithfully implement the Taiwan Relations Act, as part of a broader commitment to the security and stability of the Indo-Pacific. Our partnership is vital given China's continued pressure campaign against Taiwan. Taiwan lost three diplomatic partners in 2018, and some international fora continued to deny the participation of representatives from Taiwan. Although China advocates for peaceful unification with Taiwan, China has never renounced the use of military force, and continues to develop and deploy advanced military capabilities needed for a potential military campaign.

The salience of defense engagements has increased as the PLA continues to prepare for contingencies in the Taiwan Strait to deter, and if necessary, compel Taiwan to abandon moves toward independence. The PLA is also preparing for a contingency to unify Taiwan with the mainland by force, while simultaneously deterring, delaying, or denying any third-party intervention on Taiwan's behalf. As part of a comprehensive campaign to pressure Taiwan, China has increased military exercises in the vicinity of Taiwan, including circumnavigation flights by the PLA Air Force and naval exercises in the East China Sea.

The objective of our defense engagement with Taiwan is to ensure that Taiwan remains secure, confident, free from coercion, and able to peacefully and productively engage the mainland on its own terms. The Department is committed to providing Taiwan with defense articles and services in such quantity as may be necessary to enable Taiwan to maintain a sufficient self-defense capability. DoD is continually engaged in evaluating Taiwan's defense needs to assist Taiwan in identifying capabilities that are mobile, survivable, and effective in resisting the use of force or other forms of coercion. Since 2008, U.S. Administrations have notified Congress of more than $\$ 22$ billion in FMS for Taiwan.

\section{NEW ZEALAND}

Since the Washington Declaration in 2012, the United States and New Zealand continue to deepen and broaden their defense relationship. The U.S.-New Zealand defense partnership will remain focused on building maritime security presence, capabilities, and awareness; cooperation to develop expeditionary defense capabilities; and sharing information to enable security cooperation and to 
prepare to respond to a range of contingencies. New Zealand contributes forces to coalition operations in Iraq and Afghanistan, to three United Nations peacekeeping missions, and to UNSCR enforcement operations.

On December 10, 2018, the U.S. Memorial for Pukeahu was unveiled in the presence of the Minister of Defence Ron Mark, U.S. Ambassador to New Zealand Scott Brown, and Randall G.

Schriver, Assistant Secretary of Defense for Indo-Pacific Security Affairs.

Photo by the U.S. Department of State

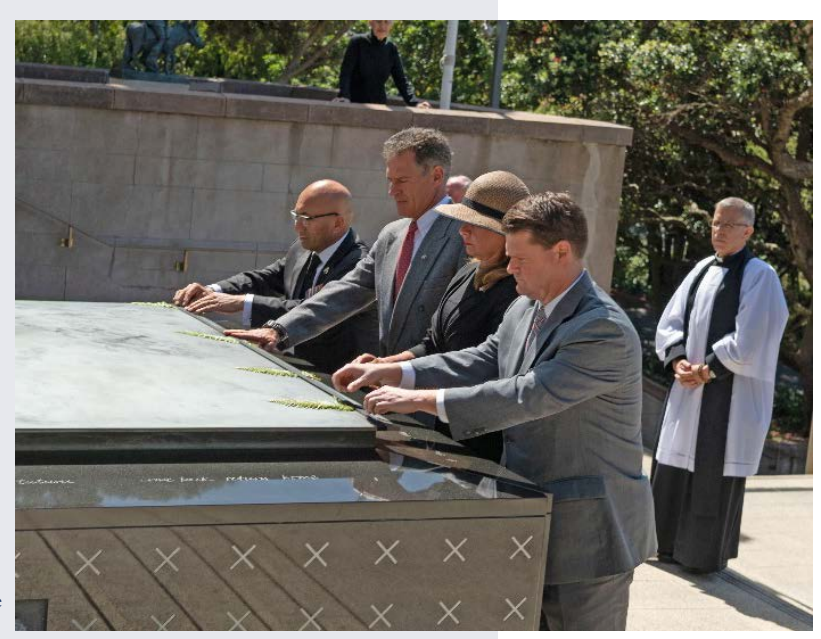

Besides these global contributions, New Zealand plays a critical role as a regional leader promoting stability, building capacity, and responding to crises and contingencies in the Pacific Islands, such as natural disasters. In 2018, New Zealand announced the "Pacific Reset," its new whole-ofgovernment policy to engage in the Pacific Islands, building capacity and resilience in response to a range of threats. By collectively stepping up in partnership with Pacific Island nations and other likeminded allies and partners, New Zealand's Pacific Reset directly complements DoD's efforts in the Indo-Pacific and our efforts to renew engagement in the Pacific. The overlap in our respective strategies creates synergies, as we collectively step up to pool our resources and respond to the Pacific's need for greater investment, infrastructure, and capacity building efforts that match the region's highest-priority needs.

\section{MONGOLIA}

Since the inception of formal bilateral defense cooperation in 1996, the U.S.-Mongolia defense relationship has developed significantly. Mongolia regards the United States as its most important "third neighbor" and primary security partner. The United States

U.N. Peacekeepers from Mongolia patrol as part of a field training exercise during Exercise SHANTI DOOT 4 in Bangladesh, March 6, 2018. Photo by Lance Cpl. Adam Montera

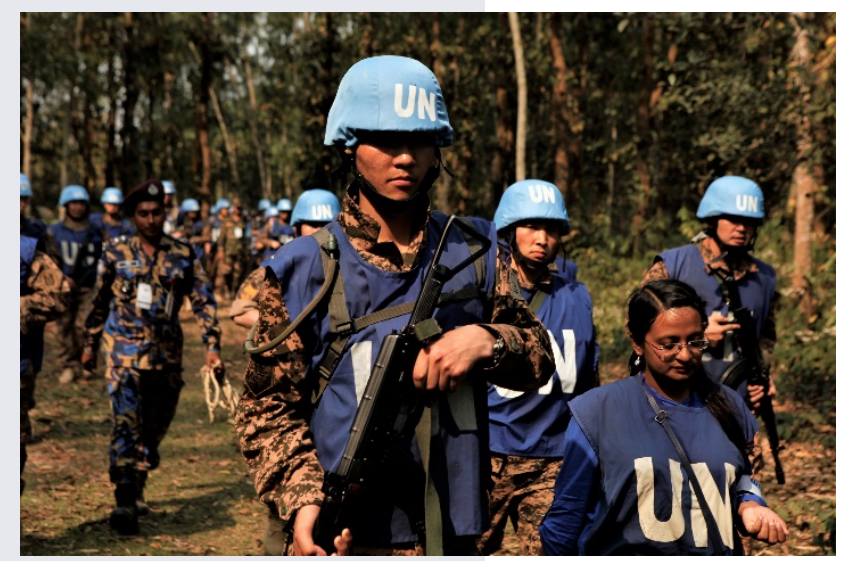

and Mongolia have a comprehensive partnership based on common values and shared strategic interests in protecting and promoting freedom, democracy, economic openness, and human rights worldwide. Mongolia remains regionally and globally engaged as a net security exporter through the Mongolian Armed Forces' contributions to the United Nations peacekeeping operations in 
Africa, and its continued deployment in Afghanistan to support coalition operations. Moreover, Mongolia continues to enforce U.N. Security Council sanctions that have been unanimously adopted in response to North Korea's unlawful nuclear and ballistic missile programs. The United States supports Mongolia's efforts to maintain and further develop a modern, professional, and selfsustaining military capable of serving as a fully integrated coalition and U.N. Peacekeeping partner. The United States also assists Mongolia with expanding its capacity to respond to domestic and regional disasters and humanitarian crises. The United States and Mongolia share a vision for a free and open Indo-Pacific that safeguards sovereignty and freedom from coercion for all countries. Mongolia's regional cooperation and support for multilateral institutions contributes to peace, stability, and prosperity in the Indo-Pacific and serves as a stabilizing influence in the region.

\section{Expanding Partnerships in the Indian Ocean Region}

The United States and India share a common outlook on the Indo-Pacific. Both countries recognize the importance of the Indo-Pacific to global trade and commerce and acknowledge that developments in this region will shape the larger trajectory of the rules-based international order. India, through its "Act East" policy, continues to make significant security, economic, and development investments to secure the vision of a free and open Indo-Pacific

"To advance our vision of a free and open Indo-Pacific, we are building new and stronger bonds with nations that share our values across the region, from India to Samoa. Our relationships will flow from a spirit of respect built on partnership, not domination."

Vice President Pence, remarks at the Hudson Institute, October 4, 2018 region. The Indian Ocean Region is at the nexus of global trade and commerce, with nearly half of the world's 90,000 commercial vessels and two thirds of global oil trade traveling through its sea lanes. The region boasts some of the fastest-growing economies on Earth, and is home to a quarter of the world's population. While the region offers unprecedented opportunity, it is also confronting a myriad of security challenges, including terrorism, transnational crime, trafficking-in-persons, and illicit drugs. To combat these challenges, the United States seeks opportunities to broaden and strengthen partnerships with India, Sri Lanka, the Maldives, Bangladesh, and Nepal to respond to shared regional challenges.

\section{INDIA}

The United States and India maintain a broad-based strategic partnership, underpinned by shared interests, democratic values, and strong people-to-people ties. The U.S.-India strategic partnership has strengthened significantly during the past two decades, based on a convergence of strategic interests, and the United States and India continue to use their deepening relationship to build new partnerships within and beyond the Indo-Pacific. 
Then-U.S. Secretary of Defense Mattis with the Indian Minister of Defence Nirmala Sitharaman during the signing of the Communications, Compatibility and Security Agreement, September 6, 2019.

Photo by Petty Officer 2nd Class Lisa Ferdinando

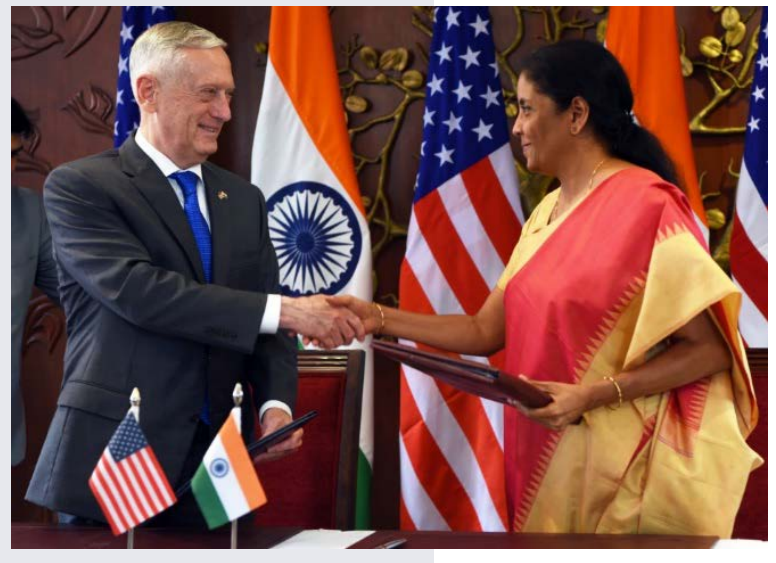

In June 2016, the United States designated India a "Major Defense Partner," a status unique to India. The designation seeks to elevate the U.S. defense partnership with India to a level commensurate with that of the United States' closest allies and partners. The establishment of the U.S.-India 2+2 Ministerial Dialogue in September 2018 also serves as a tangible demonstration of our commitment to promoting the shared principles of a free and open Indo-Pacific.

The United States continues to pursue a range of initiatives with India to enable cooperation, strengthen our interoperability, and establish a strong foundation for defense trade, technology sharing, industrial collaboration, and broader cooperation on defense innovation. The signing of the Communications, Compatibility and Security Agreement in 2018 represents a significant development in our military-to-military relationship, facilitating greater interoperability and real-time secure information-sharing. DoD and the Indian Ministry of Defence are increasing the scope, complexity, and

During MALABAR 2018, an Indian Navy oiler conducts an underway replenishment training exercise with a U.S. warship, enabled by the implementation of the U.S.-India Logistics Exchange Memorandum of Agreement.

Photo by Mass Communication Specialist 2nd Class William McCann frequency of our military exercises.

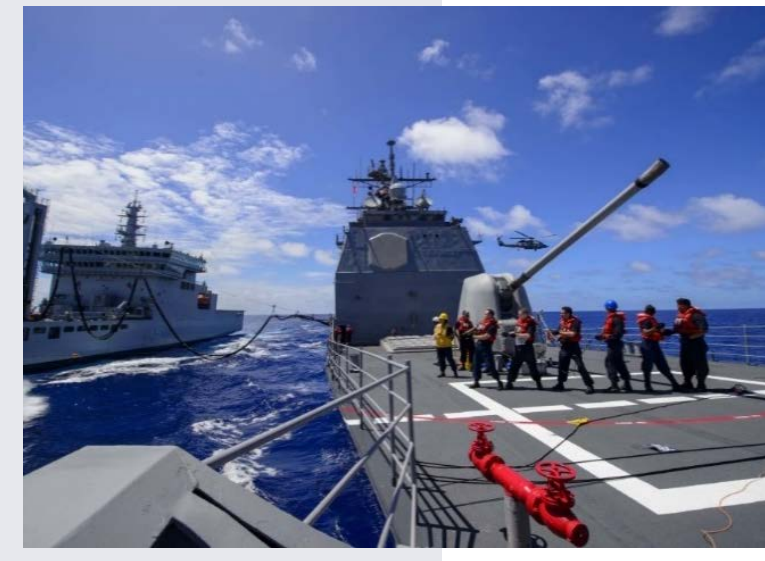
Later this year, the United States and India will conduct our first tri-service exercise, and we continue to collaborate on maritime security and domain awareness, HA/DR, counterpiracy, counter-terrorism, and other transnational issues.

As our shared interests and security cooperation have expanded, U.S.India bilateral defense trade and technology cooperation have also grown, with approximately $\$ 16$ billion in defense trade since 2008. Through the Defense Technology and Trade Initiative, we are increasing cooperation in defense technology, building industry-toindustry ties, and identifying opportunities for the co-development and co-production of defense systems for the sustainment and modernization of military forces. 


\section{SRI LANKA}

Since 2015, DoD has strengthened its relationship with Sri Lanka and increased military engagements significantly, particularly with the Sri Lankan Navy. In 2017, we conducted the first port visit in 30 years by a U.S. aircraft carrier - the USS NIMITZ Carrier Strike Group - and the first ever bilateral Cooperation Afloat Readiness and Training (CARAT) Exercise. In 2019, we increased cooperation on mutual logistics arrangements in support of Indian Ocean security and disaster response.

\section{THE MALDIVES}

Following the recent democratic transition in the Maldives, the United States has begun to explore avenues to expand security cooperation, with particular emphasis on providing capacity-building opportunities to the Maldives National Defence Forces and Maldivian Coast Guard. Key areas of focus include: maritime domain awareness (MDA) - to enable Maldivian forces the ability to monitor and patrol its sovereign maritime area and contribute to regional efforts to protect sea lines of communication; HA/DR readiness; and counter-terrorism capability. An additional $\$ 7$ million in FY 2018 Foreign Military Financing (FMF) will support these efforts.

\section{BANGLADESH}

The United States enjoys a strong defense relationship with Bangladesh, an important partner for regional stability and security. Security cooperation focuses on key areas such as maritime security and domain awareness, counterterrorism, $\mathrm{HA} / \mathrm{DR}$, peacekeeping, and border security. The annual Bilateral Defense Dialogue between USINDOPACOM and the Bangladesh Armed Forces Division sets the strategic direction of our defense relationship. In addition, recent increases in FMF, International Military Education and Training (IMET), and the inclusion of

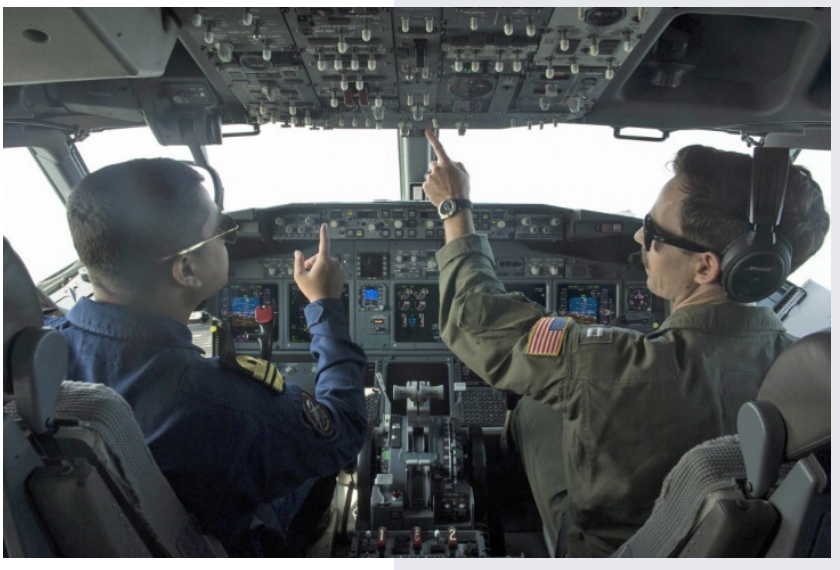
United States and Bangladesh naval officers pilot a P-8 during the CARAT Exercise in 2018. Bangladesh in the Maritime Security Initiative (MSI) underscores not only the value the United States places on its defense partnership with Bangladesh, but also Dhaka's contributions towards regional stability in support of upholding a rules-based international order in South Asia and the Indian Ocean Region. 


\section{NEPAL}

Commander of the U.S. Indo-Pacific Command Admiral Phil Davidson visits Nepal, January 11, 2019.

Photo by Petty Officer 1st Class Robin Peak

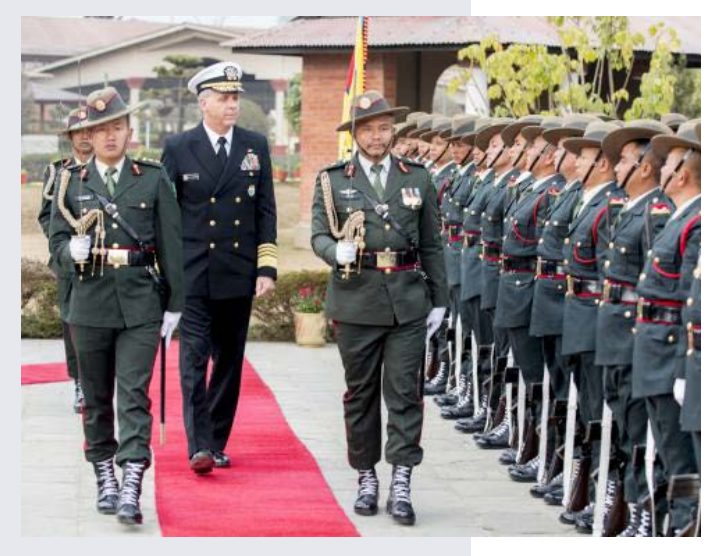

The United States seeks to expand our defense relationship with Nepal, focused on HA/DR, peacekeeping operations, defense professionalization, ground force capacity, and counter-terrorism. Our growing defense partnership can be seen in the establishment of the U.S. Army Pacific-led Land Forces Talks in June 2018, our seniormost military dialogue with Nepal. This year has already seen several senior-level visits to Nepal by the USINDOPACOM Commander and Deputy Assistant Secretary of Defense for South and Southeast Asia to further advance our defense relationship.

\section{Expanding Partnerships in Southeast Asia}

After nearly 50 years of service in the U.S. Coast Guard, the Hamilton-class cutter (WHEC-722) was officially transferred to the Vietnam Coast Guard under the name CSB-8020. A transfer ceremony took place at Coast Guard Base, Honolulu, May 25, 2017.

Photo by Petty Officer 2nd Class Melissa McKenzie

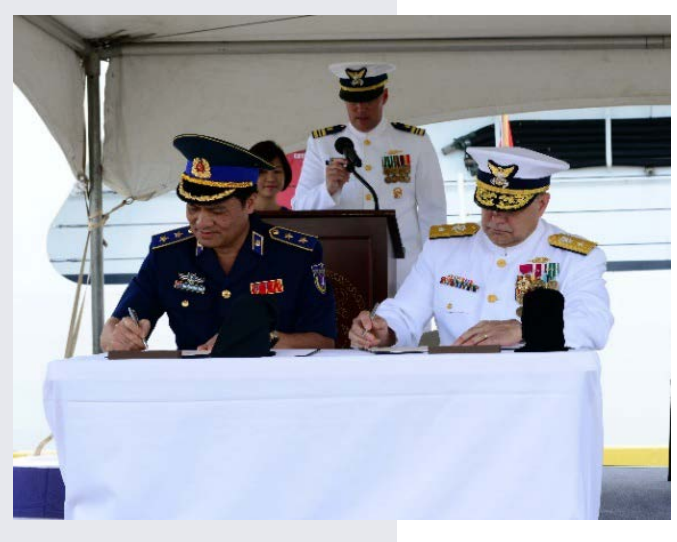

Through the implementation of the National Defense Strategy in the IndoPacific, the United States is prioritizing new relationships with Vietnam, Indonesia, and Malaysia - key players in ASEAN that remain central in our efforts to ensure peace and underwrite prosperity in the Indo-Pacific. All three countries represent engines of economic growth that are strategically located on key sea lanes between the Indian and Pacific Oceans. While maintaining independent foreign policies, Vietnam, Indonesia, and Malaysia are aligned with the region's shared vision for a free and open Indo-Pacific and are focused on maintaining peace, stability, and prosperous economic development in the region.

\section{VIETNAM}

The Department is building a strategic partnership with Vietnam that is based on common interests and principles, including freedom of navigation, respect for a rules-based order in accordance with international law, and recognition of national sovereignty. The U.S.-Vietnam defense relationship has 
grown dramatically over the past several years, as symbolized by the historic March 2018 visit of a U.S. aircraft carrier for the first time since the Vietnam War.

The Department is working to improve Vietnam's defense capabilities by providing security assistance, including Scan Eagle Unmanned Aerial Vehicles, T-6 trainer aircraft, a former U.S. Coast Guard highendurance cutter, and small patrol boats and their associated training and maintenance facilities. The U.S. military also engages in numerous annual training exchanges and activities to enhance bilateral cooperation and interoperability with the Vietnam People's Army, Air Force, Navy, and Coast Guard. Additionally, DoD has provided training and technical assistance to support Vietnam's 2018 deployment of a medical unit to the U.N. Peacekeeping Mission in South Sudan, and will continue to provide assistance to facilitate future deployments.

Our increasingly strong defense ties are based on a foundation of close cooperation to address legacy of war and humanitarian issues, which predates the restoration of diplomatic relations in 1995. As we look to celebrate 25 years of diplomatic relations in 2020, DoD remains committed to supporting U.S. efforts to clean up dioxin contamination and remove unexploded ordnance, and appreciates Vietnam's continued assistance to account for U.S. personnel missing from the Vietnam War.

\section{INDONESIA}

As the world's second and third largest democracies, the United States and Indonesia share many common strategic interests, and this year celebrate 70 years of diplomatic relations. The United States supports Indonesia's vision to become a "global maritime fulcrum" straddling the Indian and Pacific Oceans. Indonesia and the United States cooperate on defense

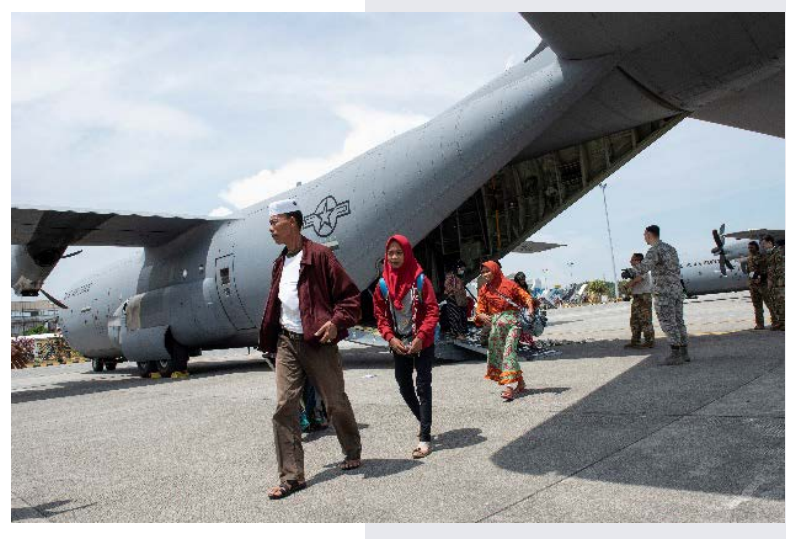

U.S. Air Force members escort displaced people off a U.S. C-130 Hercules aircraft in Balikpapan, Indonesia, October 9, 2018. Thousands were displaced after a 7.5 magnitude earthquake and tsunami struck Indonesia's Sulawesi Island. issues under the auspices of the U.S.-Indonesia Comprehensive Partnership, reaffirmed in October 2015. The Strategic Partnership focuses on six areas for advancing defense cooperation: maritime security and domain awareness; defense procurement and joint research and development; peacekeeping operations and training; professionalization; HA/DR; and countering transnational threats such as terrorism and piracy.

The United States and Indonesia conduct an active exercise program that enhances our respective capacity and interoperability based on common platforms such as F-16 fighters and Apache attack helicopters. Our bilateral defense activities include more than 200 bilateral military engagements a year, one Joint Staff sponsored exercise, and several service-level maneuver exercises annually. 
Indonesia is a major recipient of IMET funds in the Indo-Pacific, which are used to enhance the military professionalization of the Army, Navy, Air Force, and Coast Guard. Future areas of collaboration include developing defense industry partnerships that will expand coordination on acquisition, technology transfer, cooperative research, industrial collaboration, and logistics support.

\section{MALAYSIA}

Malaysia is a key player in Southeast Asia and we will continue to deepen our security and defense cooperation. Our ties have remained strong for many years, and we are working with the Pakatan Harapan Government to further strengthen this important relationship. Malaysia's regional leadership role, technologically advanced industry, sizeable economy, and capable military make it an important partner in securing peace and prosperity in Southeast Asia. Malaysia has demonstrated the capacity and resolve to contribute to regional security, and we continue to support Malaysia's emerging security requirements.

We conduct more than 100 defense engagements with Malaysia annually, including exercises, subject matter expert exchanges, and partner on common objectives such as maritime security and counter-terrorism. We improve our interoperability through combined air, maritime, and amphibious training in multiple locations across the country. At sea we participate in both the CARAT and Southeast Asia Cooperation and Training (SEACAT) Exercises and are increasing cooperation with Malaysia's maritime law enforcement agency, in coordination with the U.S. Department of State. Through the MSI, we are helping Malaysia improve its MDA by providing sensors on existing platforms. We are deploying a U.S.

\section{THE STATE PARTNERSHIP} PROGRAM IN THE INDO-PACIFIC

The State Partnership Program began in 1993 with partnerships between the National Guard of designated U.S. States and newly independent Eastern European countries. The State Partnership Program has since expanded to other regions, including the Middle East, Africa, Latin America, Western Europe, and the Indo-Pacific.

By the end of FY 2019, the United States will have 79 partnerships with 86 nations, 12 of which are in the Indo-Pacific:

- Bangladesh / Oregon (2008)

- Cambodia / Idaho (2009)

- Indonesia / Hawaii (2006)

- Malaysia / Washington (2017)

- Mongolia / Alaska (2003)

- Philippines / Hawaii, Guam (2000)

- Thailand / Washington (2002)

- Tonga and Fiji / Nevada (2014 \& 2018)

- Vietnam / Oregon (2012)

Recently Added:

- Nepal (2019)

- Sri Lanka (2019) 
maritime advisor to Malaysia to improve our partnership and coordination on maritime security and MDA. Malaysia also actively partners in international counter-terrorism efforts, adding its regional perspective to support the global effort to defeat ISIS.

Malaysia has been a critical partner of increasing importance in the region ever since the United States elevated the relationship to a Comprehensive Partnership in 2014. Malaysia is a leader on several key regional security challenges in Southeast Asia, particularly maritime security and countering violent extremism. For example, Malaysia participates in multilateral air and maritime patrols in the Malacca Strait with Indonesia, Singapore, and Thailand, focused on countering threats to international shipping in that vital waterway. Malaysia also participates in similar patrols in the Sulu and Celebes Seas with Indonesia and the Philippines aimed at countering violent extremists. The Malaysia Maritime Enforcement Agency formally committed to host the Southeast Asia Maritime Law Enforcement Initiative (SEAMLEI) Commanders' Forum in December 2019. Malaysia plays a leadership role on HA/DR, and currently co-chairs the ASEAN Defense Ministers' Meeting Plus (ADMM-Plus) HA/DR Experts' Working Group with the United States.

The Malaysian Armed Forces have demonstrated the professionalism, capacity, and resolve to contribute to regional security and international U.N. missions. We will continue to work closely with Malaysia to advance these and similar efforts which support a free and open Indo-Pacific.

\section{Sustaining Engagements, Strengthening Foundations}

As outlined in the Treaty of Amity and Cooperation in Southeast Asia of 1976, Brunei, Laos, and Cambodia embrace ASEAN values including, but not limited to, the mutual respect for the independence, sovereignty, equality, territorial integrity, and national identity of all nations; the right of every state to lead its national existence free from external interference, subversion, or coercion; and the settlement of differences or disputes in a peaceful manner. These principles underscore the importance of the sovereignty of all nations, and are in line with the U.S. vision for a free and open Indo-Pacific. While the United States maintains measured engagements with Brunei, Laos, and Cambodia, we continue to seek opportunities to enhance defense relations as conditions permit.

\section{BRUNEI}

Military-to-military ties have become a mainstay of the U.S.-Brunei bilateral relationship. The Bruneian Government has welcomed the growth of military ties with the United States and likeminded nations, including with respect to enhancing MDA. In 2018, in addition to the Brunei Navy's participation in the RIM OF THE PACIFIC Exercise and holding our annual bilateral CARAT Exercise, the Royal Brunei Land Forces and U.S. Army conducted their first bilateral exercise PAHLAWAN WARRIOR - in Brunei. This year the United States co-hosted with Brunei a multilateral Cooperation Against Transnational Threats workshop. We continue to look for ways to expand our military-to-military cooperation, including through increased information sharing. 


\section{LAOS}

Strategically located in the geographic heart of ASEAN and the Mekong sub-region, Laos presents opportunities for deepening security, economic, and diplomatic engagement. China is increasingly focused on Laos, and Beijing continues efforts to expand its strategic footprint through large debtfueled investments, especially in infrastructure and energy. However, Laos is wary of overdependence and is seeking to diversify its partners and

Deputy Assistant Secretary of Defense Joseph H. Felter with a Lao Unexploded Ordnance disposal team at a cleanup site in southern Laos, January 18, 2019.

Photo by the U.S. Department of Defense

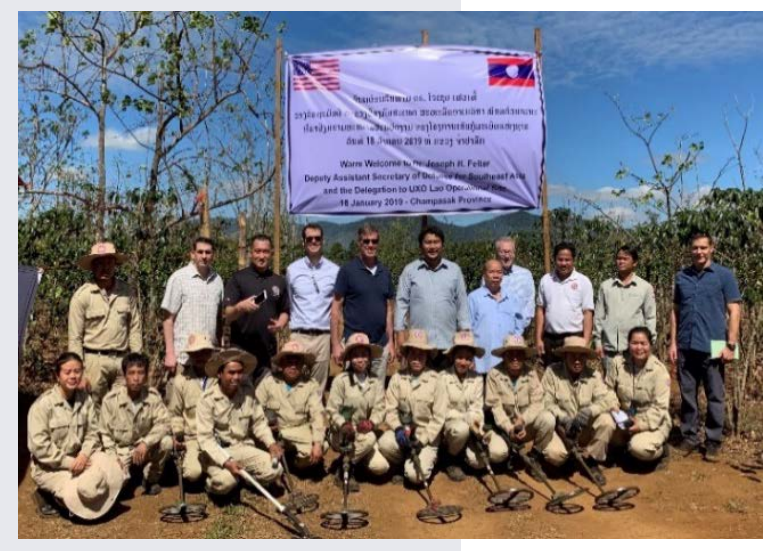
options. At the same time, Laos is experiencing a significant demographic shift - with a large majority of its population under the age of 35 - which presents a unique opportunity to engage a new, outward looking generation. The Lao military prioritizes Vietnam, Russia, and to a lesser degree China as its primary security partners. At the same time, the Laotian military is slowly expanding its international engagement portfolio, first to ASEAN and to a lesser degree to countries in the region such as Japan, Australia, and India.

The United States supports activities that advance Laos' integration into ASEAN, such as defense modernization, interoperability, English language proficiency, and respect for a rules-based international order. In the meantime, we are working to move past war legacy issues related to the Vietnam War and aim to conclude Prisoner of War/Missing in Action recovery operations honorably, and by 2030 to make Laos substantially risk-free of U.S.-sourced unexploded ordnance.

\section{CAMBODIA}

DoD seeks to build a productive military-to-military relationship with the Kingdom of Cambodia that protects its sovereignty, promotes military professionalism, and helps it become a responsible and capable contributor to regional security. In early 2017, Cambodia suspended all military-to-military exercises with the United States. We, however, continue to cooperate in peacekeeping operations, humanitarian mine action, medical research, and U.S. Missing in Action personnel accounting.

\section{Revitalized engagements in the Pacific Islands}

We are revitalizing our engagement in the Pacific Islands to preserve a free and open Indo-Pacific region, maintain access, and promote our status as a security partner of choice. The Pacific Islands represent a region distinct from other regions in the Indo-Pacific because of the relatively small size of states, unique geography, and challenges to promote economic prosperity. As a Pacific nation itself, 
the United States views the Pacific Islands as critical to the U.S. strategy because of our shared values, interests, and commitments, including U.S. security guarantees to the Freely Associated States. Our shared interests with the Pacific Islands underscore

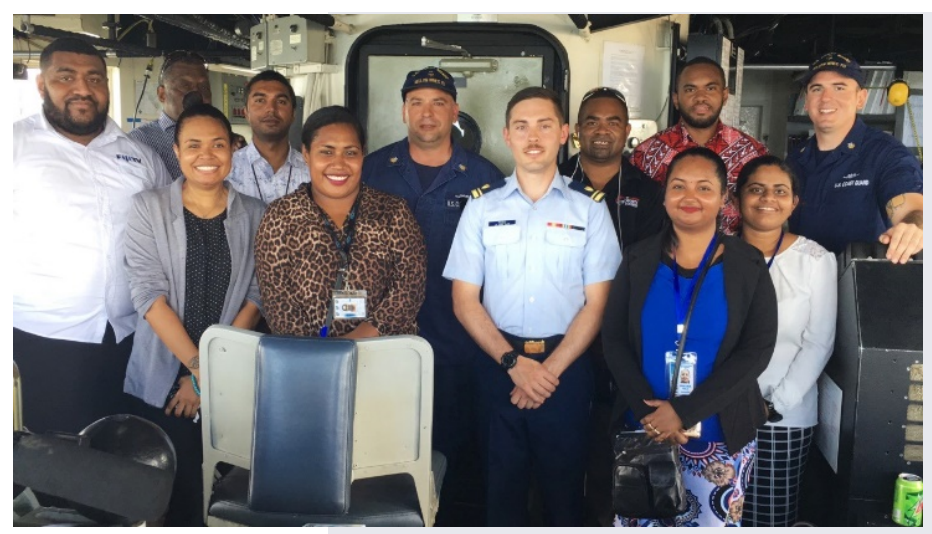

U.S. Coast Guard Cutter Mellon was in Fiji from January 22-25, 2019, to exercise the bilateral Shiprider Agreement recently signed between Fiji and the United States. four important components special to this region.

First, we share a long history, born from commitments and support during the Second World War that compels a renewed U.S. commitment to stay. Second, we believe strongly in respect for a safe, secure, and prosperous, free and open Indo-Pacific that must preserve small states' sovereignty. Third, we aim to focus on building capacity and resilience to address maritime security; Illegal, Unreported, and Unregulated fishing; drug trafficking; and resilience to address climate change and disaster response, as signified by the 2018 Boe Declaration. Fourth and finally, we are committed to continued engagement in the region, by reaffirming and renewing partnerships.

Of the Pacific Islands, three have militaries: Papua New Guinea, Fiji, and Tonga. The United States works with each to support improved capability within partner armed forces and, consistent with a partner-centric approach, often in support of efforts from allies and partners such as Australia and New Zealand.

The United States has a unique relationship with the Freely Associated States. The Compacts of Free Association are treaty-like agreements

\section{COAST GUARD PARTNERSHIPS WITH THE PACIFIC ISLANDS}

The U.S. Coast Guard operations within the Pacific Islands have been steady over the past half century. The Coast Guard's presence is permanent and its partnerships enduring. The Coast Guard provides unique access, influence, and trust due to its routine interactions with the Pacific Islands to address shared maritime safety, security, and governance challenges.

- The U.S. Coast Guard represents USINDOPACOM at the Pacific Quadrilateral Defense Coordinating Group, a Pacific Consortium (the United States, France, Australia, and New Zealand) that supports counter-Illegal, Unreported, and Unregulated fishing enforcement through multilateral and bilateral operations with 15 Pacific Island nations, bringing considerable economic and security benefits to the participant nations.

- The U.S. Coast Guard shiprider agreements allow 11 Pacific Island nations to exercise sovereignty in their exclusive economic zone through U.S. Coast Guard and U.S. Navy ship deployments.

- The U.S. Coast Guard partners with the U.S. Navy on Oceania Maritime Security Initiative deployments. 
which provide security and financial support to the Federated States of Micronesia, the Republic of the Marshall Islands, and the Republic of Palau. These nations are important and historic U.S. partners in the Pacific, with deep ties to the United States.

Assistant Secretary of Defense for IndoPacific Security Affairs Randall G. Schriver announces a new partnership between the Nevada National Guard and Fiji in Suva, December 14, 2018.

Photo by the U.S. Department of Defense

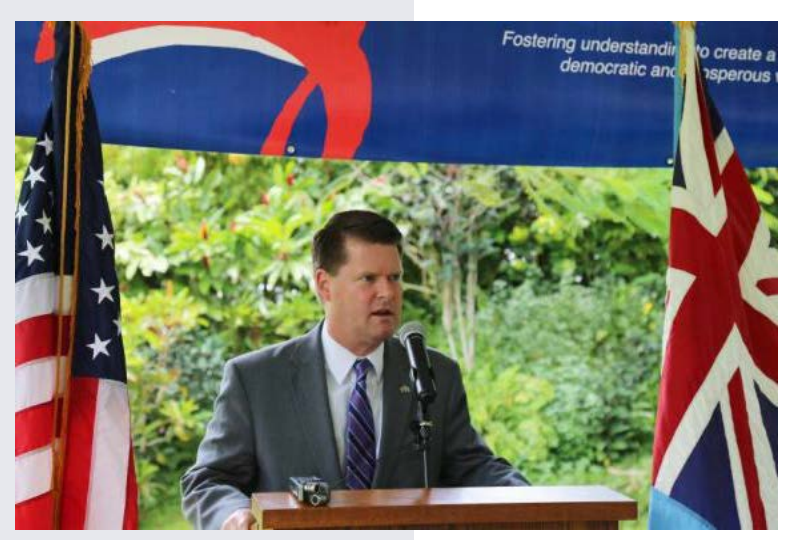

U.S. security support to the Pacific Islands comes in many other forms as well. Many Pacific Island countries participate in various regional exercises and training events, including USINDOPACOM's KOA MOANA and PACIFIC PATHWAYS Exercises. We have increased the number of ship visits and, in turn, shiprider agreements that we have exercised. We are increasingly supportive of capacity building across the Pacific Islands, which includes at least $\$ 7$ million in FMF in 2018 to support Papua New Guinea, Fiji, and Tonga. Additionally, the United States is working with Palau to improve its MDA to enhance Palau's maritime law enforcement capability.

\section{Engagements with Other Allies}

\section{THE UNITED KINGDOM, FRANCE, AND CANADA}

Allies such as the United Kingdom, France, and Canada play a critical role in maintaining a free and open Indo-Pacific. In addition to military capability and regional presence, these allies contribute vital support to upholding free and open principles in the region and globally.

For example, the United Kingdom has increased deployments and operations in the region since

\section{In FY 2018, the Department challenged 40 different maritime claims of 26 claimants. Many of these excessive claims were challenged persistently, throughout the year, in the course of routine, daily operations.}

"The U.S. military is active on a daily basis to safeguard freedom of navigation and overflight in the Indo-Pacific, demonstrating our commitment to fly, sail and operate wherever international law allows."

Assistant Secretary of Defense Randall G. Schriver, speech at American Enterprise Institute, August 7, 2018

2017, contributed to the coordinated, multinational initiatives to enforce UNSCR sanctions on North Korea, and performed its first naval operation aimed at asserting navigational rights and freedoms in the South China Sea in 2018 with the transit of its frigate 
HMS SUTHERLAND and amphibious transport HMS ALBION, followed by the transit of its frigate HMS ARGYLL in 2019. The United Kingdom shares our holistic view of the region as the "Indo-Pacific," as well as the importance of strengthening alliances and partnerships with countries in the region.

The United States and France have restarted the Indo-Pacific Security Dialogue, and recognized the significance of the extended

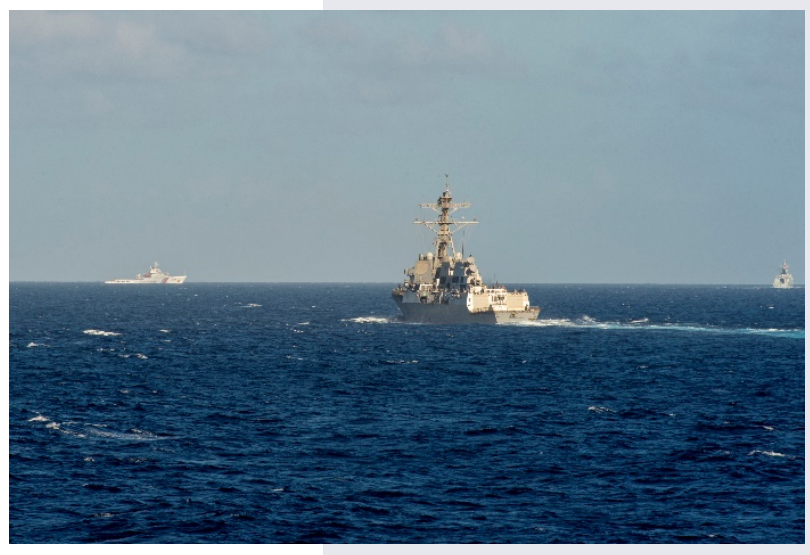

Arleigh Burke-class guided-missile destroyer USS SPRUANCE and Arleigh Burke-class guided-missile destroyer USS

PREBLE conduct freedom of navigation operations in the South China Sea.

Photo by the U.S. Department of Defense

\section{UPHOLDING FREEDOM AND ACCESS TO GLOBAL COMMONS}

Throughout our history, the United States has asserted a key national interest in preserving the freedom of the seas, and has often relied on the U.S. military forces to protect that interest. As President Ronald Reagan said in releasing the U.S. Oceans Policy in 1983, "we will not acquiesce in unilateral actions of other states designed to restrict the rights and freedoms of the international community in navigation and overflight." Today, in places like the South China Sea, excessive maritime claims are attempts by coastal States to unlawfully restrict the exercise of freedoms afforded to all seafaring nations to operate in waters beyond territorial limits. The United States will continue to fly, sail, and operate wherever international law allows, and encourage our allies and partners to do the same.

Excessive maritime claims inconsistent with international law, if left unchallenged, threaten the international rulesbased order and U.S. interests and those of our regional allies and partners. Freedom of the seas is essential to ensuring the global mobility of U.S. forces in the event of a crisis and the worldwide security of civilian shipping on a daily basis. DoD, therefore, is committed to ensuring free and open maritime access, including through freedom of navigation (FON) assertions (commonly called Freedom of Navigation Operations, or FONOPs), to protect the stable economic order and to maintain the ability of U.S. forces to respond, as needed. The FON program is carefully designed to challenge coastal states' excessive maritime claims while respecting their rights under international law.

The FON program protects long-standing principles of freedom of navigation for civilian and military vessels through both diplomatic and operational challenges, refusing to acquiesce to excessive maritime claims wherever they are made. FONOPs serve to protect the rights, freedoms, and lawful uses of the sea and airspace guaranteed to all nations under international law. They are not targeted at any particular country, and they have no bearing on sovereignty disputes over land features. FONOPs are conducted peacefully and impartially, in accordance with international law. Consequently, U.S. forces routinely challenge excessive maritime claims asserted by allies and partners, as well as those made by potential adversaries and competitors. 
deployment of the aircraft carrier FNS CHARLES DE GAULLE to the Indo-Pacific in 2019, accompanied for portions of its deployment by ships from other NATO countries, Australia, and the United States. France additionally supports UNSCR enforcement and shares our emphasis on developing a network of strategic partnerships, contributing to the building of a regional security architecture, and engaging in multilateral dialogue platforms, in its strategy on France and Security in the Indo-Pacific.

Canada is contributing to UNSCR enforcement, to include providing a maritime patrol aircraft during summer 2018. A Canadian officer was also appointed the first non-U.S. Deputy Commander of United Nations Command in 2018. Canada is also expanding defense cooperation with partners in the region such as Vietnam, with future efforts expected to focus on advancements in personnel training, U.N. peacekeeping operations, and increased defense industry ties.

\subsection{Line of Effort 3: Promoting a Networked Region}

Shared security in the Indo-Pacific continues to rest on U.S. military presence and a growing network of alliances and close partnerships that promote interoperability and coordination.

As the Indo-Pacific changes, the United States is augmenting its bilateral relationships with trilateral and multilateral arrangements, and encouraging intra-Asian security relationships for partnerships with purpose. As articulated in the National Defense Strategy, DoD will strengthen and evolve our alliances and partnerships into an extended network capable of deterring or decisively acting to meet the shared challenges of our time. In the Indo-Pacific, this includes a networked security architecture capable of deterring aggression, maintaining stability, and ensuring free access to common domains.

\section{PARTNERSHIPS WITH PURPOSE}

An important example of partnerships with purpose is the Enforcement Coordination Cell (ECC) in Yokosuka, Japan. Commanded by USINDOPACOM and executed by U.S. Seventh Fleet, the United States is working sideby-side with South Korea, Japan, Australia, New Zealand, Canada, France, and the United Kingdom at a single headquarters to enforce the UNSCR sanctions regime against North Korea and the illicit transfer of oil and ship-to-ship transfers in the East China Sea and Korea Bay. The ECC allows us to work closely with our allies and partners to manage, coordinate, and de-conflict our efforts and is an important facilitator of transparent collaboration between our allies and partners at sea and in the air.

In a large and interconnected region, especially one with so many strong, capable, and dedicated players, it is prudent to network and link relationships to produce gains for all. As we weave together 
these partnerships with purpose, a networked security architecture - with its shared values, habits of cooperation, and compatible and complementary capabilities - will form a strong free and open fabric that knits the region together, preserving sovereignty and regional peace and stability for years to come. This is a vision the United States has long advanced in the Indo-Pacific, and one we believe will continue to benefit the region in terms of stability and prosperity.

\section{TRILATERAL PARTNERSHIPS}

First, the Department is strongly emphasizing trilateral mechanisms to bring together like-minded allies and partners to maximize individual contributions to regional peace and security and link together nations that previously worked with us mostly separately. The region is more secure when we combine efforts in this way and we will continue to prioritize these important mechanisms.

The ROK, Japan, and the United States trilateral partnership is critical to peace and security in the IndoPacific region. Our three democracies share the common goals of upholding a rules-based international order; achieving the final fully-verified denuclearization of North Korea; and strengthening the network of like-minded nations in the region. Toward these ends, the ROK-Japan-United States trilateral

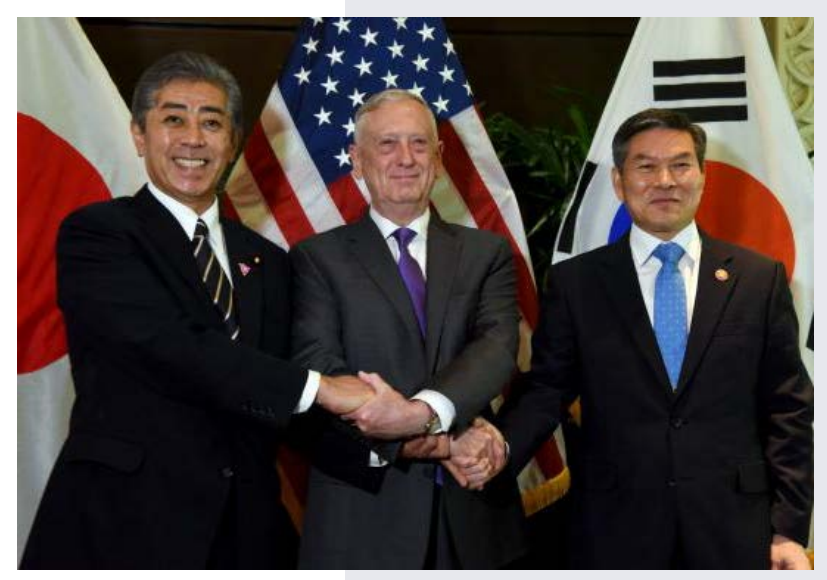

Then-U.S. Secretary of Defense Mattis meets Japan's Defense Minister Takeshi Iwaya and the ROK Defense Minister Jeong Kyeong-doo for the U.S.-Japan-South Korea trilateral at the ASEAN Defense Ministers' Meeting Plus, October 19, 2018.

Photo by Lisa Ferdinando defense partnership continues practical cooperation on UNSCR enforcement; information sharing; anti-submarine warfare; BMD; mine counter-measure warfare; and HA/DR efforts. The United States is committed to further strengthening and growing our trilateral defense cooperation to meet future regional and international challenges.

The United States is also developing its trilateral partnership with Japan and Australia. Together, we are cooperating in tangible ways to enhance security across the region and increase our interoperability, in part, by augmenting our exercises and training; increasing information sharing; and building capabilities. For example, we are taking what would otherwise be separate or bilateral capacitybuilding initiatives in Southeast Asia and ensuring that they not only complement one another, but are also tailored to assist in building up more comprehensively capable partners. This grouping is also effectively improving our interoperability by trilateralizing and multilateralizing key military exercises, including COPE NORTH GUAM and SOUTHERN JACKAROO.

The United States, India, and Japan also enjoy a robust trilateral partnership. The annual naval exercise, MALABAR, which began as a U.S.-India exercise, has included Japan as a participating 
MALABAR 2018 was the $22^{\text {nd }}$ rendition of the exercise and the first time hosted off the coast of Guam.

Photo by the U.S. Department of Defense

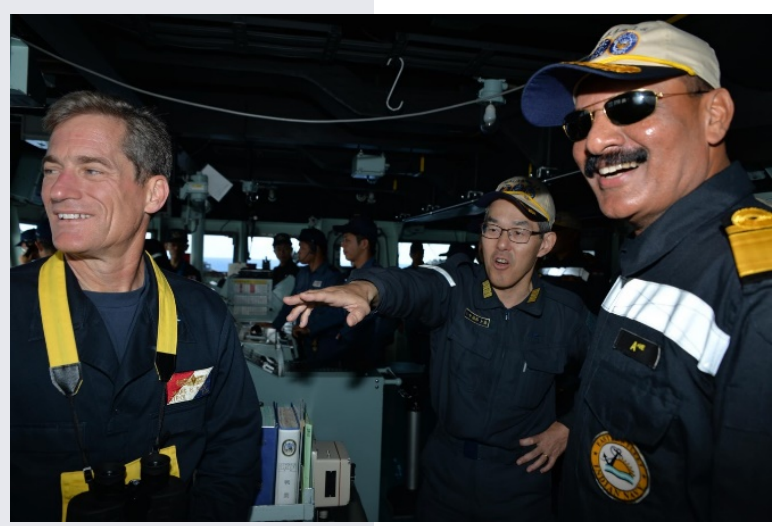

partner since 2014. The exercise has increased our ability to operate trilaterally, including via real-time information sharing, and has increased in complexity over time to incorporate surface, amphibious, and air components. Underpinning this cooperation is the State Departmentled trilateral dialogue which completed its 9th iteration in April 2018. This dialogue trilateral cooperation in the areas of connectivity and infrastructure development, counter-proliferation, counterterrorism, maritime security and domain awareness, and HA/DR. The first-ever trilateral meeting between the leaders of the United States, India, and Japan took place in November 2018 at the G20 meeting.

\section{STRENGTHENING REGIONAL INSTITUTIONS THROUGH} MULTILATERAL ENGAGEMENT

The United States continues to support ASEAN centrality in the regional security architecture, and the U.S. free and open Indo-Pacific strategy seeks to further empower it. The United States and ASEAN share common values, and ASEAN is a key partner in promoting the values and policies enshrined in the U.S. Indo-Pacific Strategy: freedom of the seas; market economics;

Commander of U.S. Indo-Pacific Command Admiral Davidson delivers a speech on the free and open IndoPacific in Singapore, March 7, 2019.

Photo by the U.S. Department of Defense

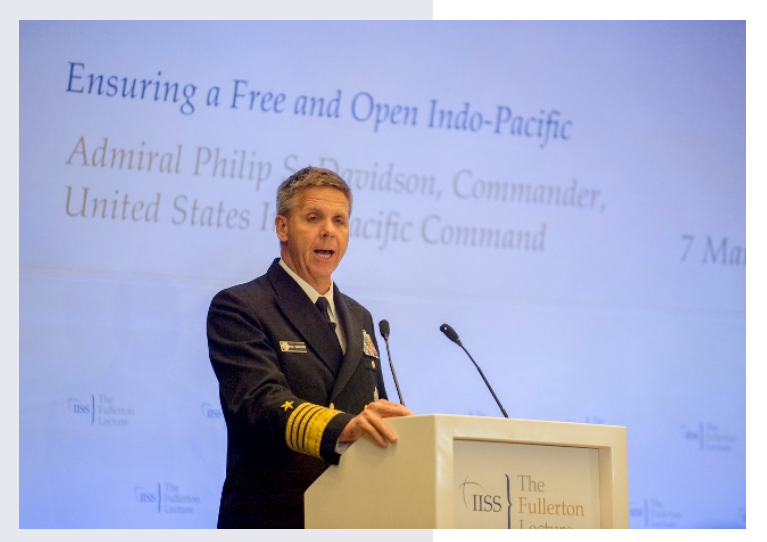
good governance; and respect for an order based on clear and transparent rules. As ASEAN nations support one another to maintain the freedom, sovereignty, and territorial integrity of countries within the region, this cohesion strengthens ASEAN's voice. The United States respects ASEAN's consensus based decision-making model, and we believe the more ASEAN speaks with one voice, the more it is able to maintain a region free from coercion.

A critical part of our engagement is meaningful work with various ASEAN-based institutions. At the group's invitation, the United States joined the East Asia Summit (EAS) - chaired by the rotating head of ASEAN - and together we have made it the region's leading forum for addressing political and 
security challenges. Since 1994, the United States has been an active member and contributor to the ASEAN Regional Forum (ARF), utilizing the forum to strengthen multilateral across a transboundary functional cooperation and non-traditional security

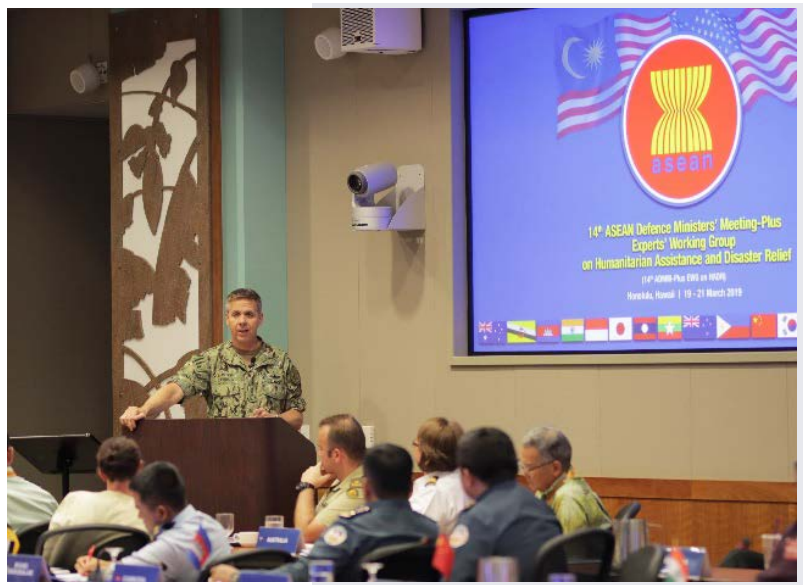
challenges facing the Indo-Pacific. The ARF, led by ministers of foreign affairs, is an ideal platform for a truly networked region. The Department has made significant progress in recent years to enhance our defense and security relationship with ASEAN. Through these efforts, we are continuing to build on the desire of ASEAN countries to better share information with one another and pursue a framework to enhance regional MDA.

The Department has enjoyed constructive engagement with our ASEAN colleagues in the ADMM-Plus and subordinate mechanisms, such as the Experts' Working Group, since the formal establishment of the ADMM-Plus in 2010. U.S. Secretaries of Defense have attended every ADMM-Plus ministerial meeting since 2010, and we have matched this participation with active engagement in the ADMM-Plus subordinate mechanisms.

In working with the ADMM-Plus, we seek to complement U.S. efforts in the EAS, the ARF, and other ASEAN fora. We use this formal multilateral engagement mechanism with ASEAN to complement our bilateral and trilateral engagements. We have bolstered our ties further by continuing to host informal U.S.ASEAN defense ministers meetings in
Admiral Davidson, Commander of U.S. IndoPacific Command, providing opening remarks at the 14 th ASEAN Defense Ministers' Meeting Plus Experts' Working Group on HA/DR co-hosted by the United States and Malaysia at the Daniel K. Inouye Asia-Pacific Center for Security Studies. 72 participants from 16 nations participated.

by the U.S. Department of Defense

BUILDING PARTNER CAPACITY, STRENGTHENING REGIONAL SECURITY NETWORKS, AND ENHANCING SHARED UNDERSTANDING

Since its inception in 1995, the Daniel K. Inouye AsiaPacific Center for Security Studies (DKI APCSS) has promoted a networked region through its executive education programs, and a network of now more than 12,000 alumni. During in-resident courses each involving over 100 fellows from more than 35 countries, multinational cohorts have developed action plans such as enhancing cross-border law enforcement information exchange, mitigating migration emergencies at sea and reducing human trafficking.

As part of MSI, the center brought together representatives from the maritime focal points and information-sharing hubs across ASEAN to develop their national and regional information sharing mechanisms, share best practices, and outline their interagency action plans to enhance maritime shared awareness in their nations and the region.

In 2019, DKI APCSS also co-hosted the Oceania National Security Policy workshop with the Pacific Islands Secretariat, which focused on the implementation of the Boe Declaration, and development of national security polices by Oceania nations. This event highlighted the importance of supporting intra-regional security relationships to share best practices and align sub-regional priorities. 
September 2016, and in June and October 2018 building on the success of our 2014 meeting.

Thailand is the ASEAN Chair for 2019, and we continue to work with Bangkok to co-organize the ASEAN-U.S. Maritime Exercise (AUMX), approved by the Defense Ministers during the ADMM in October. The AUMX will take place in September 2019 in Bangkok and international waters in Southeast Asia. This type of forward-leaning action by Thailand is a key example of its intent and resolve to be a sub-regional leader. We continue to look for other ways and means to support this type of effort through the SEAMLEI, previously known as the Gulf of Thailand Initiative on Maritime Law Enforcement, which convenes the Coast Guards or maritime law enforcement agencies of ASEAN member states to increase maritime law enforcement cooperation and information sharing. SEAMLEI builds technical capacity using the latest technology for MDA, while also providing a platform for dialogue among decision-making officials.

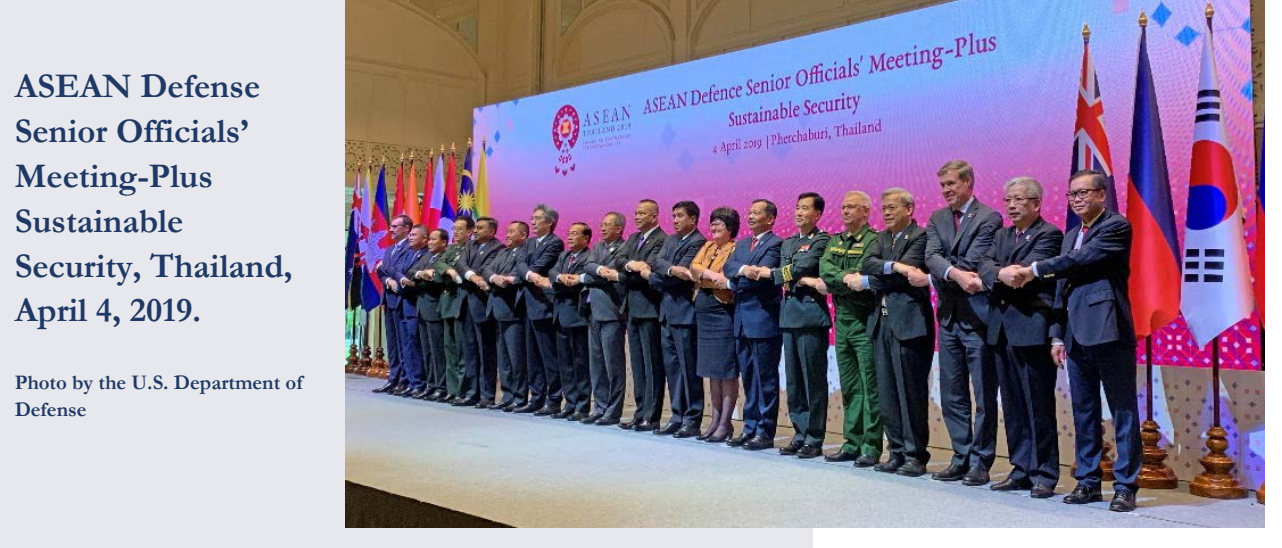

In October 2018, the ASEAN Defense Ministers agreed to conduct the first AUMX, which Thailand agreed to organize. To fulfill this commitment, the United States intends to focus on the promotion of maritime security and safety via shared awareness, technical cooperation, and sharing of knowledge and expertise between the United States and ASEAN. The United States is also examining the viability of working with a willing ASEAN member state and ADMM-Plus partners to increase the English language training (ELT) capacity for ASEAN military and defense officials. This concept proposes joining efforts among ELT stakeholders to support a multinational ELT venue that facilitates common learning, cultivates trust and confidence, and helps build a cadre of English speaking counterparts across ASEAN defense establishments.

The Department also supports the recent re-establishment of the diplomatic quadrilateral consultations - or Quad - between the United States, Australia, India, and Japan, which has convened three times at the Assistant Secretary-level since November 2017. The Quad is an important forum to discuss the respective Indo-Pacific visions of the four countries, all grounded in an affirmation of ASEAN centrality and building on existing trilateral relationships. Consultations focus on upholding the rules-based order in the Indo-Pacific, increasing connectivity consistent with international law and standards, and coordinating on counter-terrorism and maritime security efforts. 


\section{EMERGING INTRA-ASIAN SECURITY RELATIONSHIPS}

Improving security relations among Indo-Pacific countries is critical to regional integration. The Department encourages our allies and partners to develop interconnected security relationships. In some cases, and in recognition of the changing security environment, countries are strengthening their bilateral, trilateral, and multilateral security relationships on their own, and in others, the Department is more directly encouraging new cooperation. As part of these growing ties, countries are signing new defense agreements and arrangements; enhancing training, exercises, and operations; and building partner capacity, helping stabilize the Indo-Pacific.

Countries in the region are recognizing the need to formalize closer security ties to safeguard shared principles, including the peaceful resolution of disputes, as the region saw with Vietnam and Australia elevating their relationship to a strategic partnership, and Japan and India significantly expanding their defense and security ties. Key countries are also working together more closely on conducting training, exercises, and even joint operations. Recent examples include, expanded Japan-Vietnam maritime exercises and Indonesia's proposal to conduct joint operations with Malaysia and the Philippines -

\section{MARITIME SECURITY INITIATIVE: YEAR FOUR}

DoD's Indo-Pacific Maritime Security Initiative (MSI) - Section 1263 of the National Defense Authorization Act (NDAA) for FY 2016 - was originally established as a five-year authority focused on building partners' maritime capacity. The NDAA for FY 2019 extended the authority through December 2025 and expanded the scope of the initiative - now designated the Indo-Pacific MSI - into South Asia. MSI authorizes the provision of training, equipment, supplies, and small-scale construction to the Philippines, Vietnam, Indonesia, Malaysia, Thailand, Sri Lanka, and Bangladesh to enhance their ability to "sense, share, and contribute" to maritime security and MDA; to create a common Regional Maritime Picture; and to empower them to observe and control more effectively their own sovereign maritime spaces, both individually and jointly.

In MSI's first three years, DoD focused on enhancing information-sharing, interoperability, and multinational maritime cooperation. To increase information-sharing, DoD has connected the MSI recipient nations' Maritime Command and Control centers through the installation of secure information-sharing networks, and Field Information Support Tool communications systems. MSI funding has also been used to field common ISR platforms such as an Aerostat, SABIR ISR sensor packages, unmanned aerial systems, and upgrades to High Endurance Cutter (WHEC) vessels to foster interoperability among the region's maritime forces. For example, the Philippines and Vietnam operate and maintain their WHECs while conducting MDA missions in the South China Sea and multinational training exercises.

With MSI support, the U.S. Navy has increased the scope of the SEACAT Exercise to make it a truly regional maritime security exercise in which partners operationalize key skills - such as interdiction and communications systems provided through MSI. MSI has also enabled DoD to contract civilian vessels for the exercise to simulate real-world interdiction and boarding scenarios more effectively. One of MSI's primary goals in FY 2019 is to enhance interoperability through common platforms. 
including maritime counter-piracy patrols in the Sulu Sea. Regional capacity-building is increasing as well, as seen with Japan's efforts to improve Philippine maritime forces and India's steps to deepen

A Royal Thai Coast

Guardsman (left), a Philippine Navy Sailor (center), and a Philippine Coast Guardsman practice tactical procedures during a Visit, Board, Search, and Seizure seminar as part of the SEACAT Exercise in Manila, August 28, 2018.

Photo by Petty Officer 1 ${ }^{\text {st }}$ Class Micah Blechner

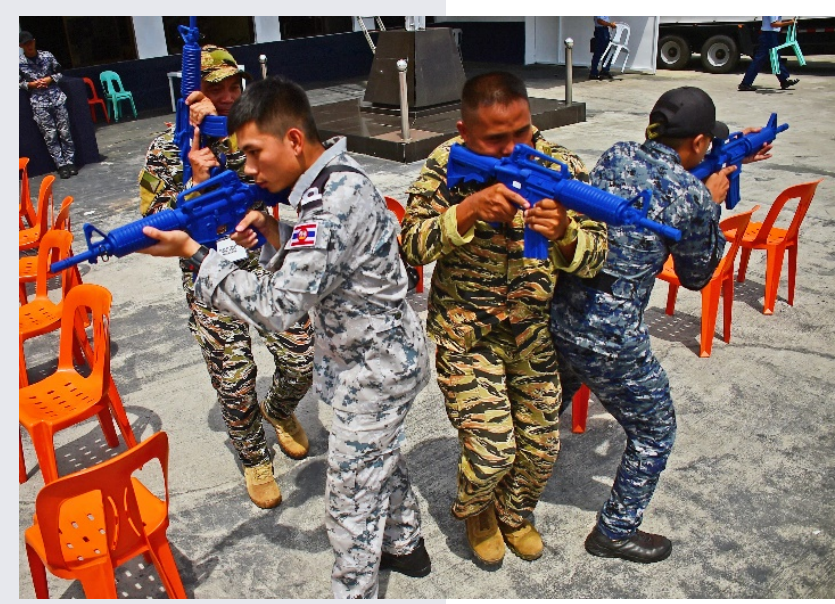

its exchanges with Vietnam. These closer relationships are not limited to bilateral ones. Last year, India hosted Japan and Australia for its first ever highlevel trilateral dialogue in New Delhi, where they discussed maritime security, and other security issues.

Singapore's Information Fusion Centre (IFC) is also an example of how countries in the region are collaborating to facilitate information sharing and enhance maritime security. Since its inception in 2009, Singapore's IFC has served as a maritime information hub for the region, contributing actionable information to regional and global navies and coast guards to cue timely operational responses to maritime threats such as piracy and drug smuggling. The IFC has hosted over 100 international liaison officers from over 20 countries. We are also encouraged by the region's efforts to establish the "Our Eyes" initiative, a platform to improve strategic information sharing between member countries.

Last December, the United States also welcomed the inauguration of India's maritime IFC, which will function as a regional platform for the exchange of information in the maritime domain among partner nations. Likewise, Sri Lanka, whose strategic location in the Indian Ocean through which 70 percent of maritime traffic passes, has outlined a vision to become a regional hub for logistics and commerce. Supporting this vision, the U.S. Navy recently initiated a series of temporary cargo transfer initiatives enabling non-lethal re-supply of passing naval vessels in Sri Lanka. These engagements serve as proof of principle for a range of initiatives that would benefit regional connectivity and security, including support to HA/DR. DoD also fully supports countries pursuing multilateral agreements and 
arrangements to enhance regional security, including the 2002 ASEAN-China Declaration of Conduct to lower tensions in the South China Sea.

The Department is also taking steps to support the law enforcement capacity and riparian domain awareness of partner countries in the Mekong region to enhance border security and combat the trafficking of drugs, wildlife, arms, and people.

Closer security relations in the region also benefit the United States' ability to resource and implement this strategy. Our National Defense Strategy states that "when we pool resources and share responsibility for our common defense, our security burden becomes lighter." Greater burden-sharing will strengthen our ability to deter conflict and increase our flexibility in responding to challenges.

\section{GLOBAL PEACE OPERATIONS INITIATIVE (GPOI)}

The Indo-Pacific contributes more than one-third of all U.N. peacekeeping personnel, and many countries have pledged additional contributions. India, Bangladesh, Nepal, and Indonesia are consistently among the top 10 U.N. peacekeeping contributing countries. These and other regional partners, such as Mongolia, provide critical enabling capabilities to U.N. operations. These contributions help promote peace and security while advancing regional cooperation, confidence building, and professionalization of security forces.

In partnership with the U.S. Department of State, USINDOPACOM will maintain strong regional partnerships through Global Peace Operations Initiative (GPOI), which is the U.S. Government's primary tool to build partner capacity to support U.N. peace operations. GPOI's 12 Indo-Pacific partners include Bangladesh, Cambodia, Fiji, Indonesia, Malaysia, Mongolia, Nepal, the Philippines, Sri Lanka, Thailand, Tonga, and Vietnam. Since 2016, GPOI has supported the U.N. Peacekeeping Course for African Partners, which brings together Indian and U.S. Army instructors annually to train African peacekeepers. Through GPOI, we will support training, exercises, equipment, and training facility enhancements with a goal of strengthening partners' preparation, deployment, and sustainment capabilities. 
INDO-PACIFIC STRATEGY REPORT

This page left intentionally blank 


\section{CONCLUSION}

he United States is a Pacific nation and has a natural and enduring interest in the Indo-Pacific. For more than 70 years the United States, along with our like-minded allies and partners, has L helped underwrite a stable security environment that allowed the people, economies, and nations in the Indo-Pacific to rise and prosper. Our vision for a free and open Indo-Pacific encompasses values shared by our allies and partners in the region - one that emphasizes upholding a foundation of mutual respect, responsibility, transparency, and accountability.

As great power competition returns, we will continue to invest, act, and orient ourselves to ensure that the principled international order from which all countries in the region benefit endures. To uphold a free and open Indo-Pacific, we will base our outreach and activities in the region on our strong alliances and partnerships. We will also enhance our posture and presence while building the capabilities of like-minded countries, as we promote a networked and more integrated region, engage our burgeoning set of partners, and invest for the future. 
The United States will uphold our commitments and will act to defend our interests and those of our allies and partners. At the same time, we maintain our expectation that our allies and partners will contribute their fair share to security by:

- Resourcing and investing sufficiently for their own defense to ensure deterrence and mitigate vulnerabilities;

- Cooperating in building partner capacity for third party partners in the region;

- Upholding a rules-based international order (i.e., flying, sailing, and operating to uphold international laws and norms);

- Providing access needed for contingency response and resiliency;

- Strengthening interoperability, including information sharing, with the United States and other like-minded countries in the region; and,

- Promoting and actively participating in region-led initiatives to uphold a free and open IndoPacific.

The United States, along with our like-minded allies and partners, will continue to be engaged in this dynamic and rapidly growing region. The Department of Defense, in conjunction with other U.S. Government Departments and Agencies, regional institutions, and regional allies and partners, will continue to ensure that the rule of law - not coercion and force - dictates the future of the IndoPacific. We will build on our successes to ensure that this region remains peaceful, prosperous, and secure for decades to come. 


\section{ACRONYMS}

A2/AD

ADMM

APEC

ARF

ASEAN

AUMX

BMD

BUILD Act

CARAT

CCP

CNMI

CFC

DoD

DPRK

EAS

ECC

EDCA

ELT

FMF

FMS

FONOP

$\mathrm{HA} / \mathrm{DR}$

IFC

IMET

ISIS

ISR

JSDF

MDA

MSI

NATO

PLA

PRC

ROK

SEACAT

SEAMLEI

UNSCR

USFK

USINDOPACOM

WHEC
Anti-Access/Area-Denial

ASEAN Defense Ministers' Meeting

Asia-Pacific Economic Cooperation

ASEAN Regional Forum

Association for Southeast Asian Nations

ASEAN-U.S. Maritime Exercise

Ballistic Missile Defense

Better Utilization of Investments Leading to Development Act

Cooperation Afloat Readiness and Training

Chinese Communist Party

Commonwealth of the Northern Mariana Islands

Combined Forces Command

U.S. Department of Defense

Democratic People's Republic of Korea

East Asia Summit

Enforcement Coordination Cell

Enhanced Defense Cooperation Agreement

English Language Training

Foreign Military Financing

Foreign Military Sales

Freedom of Navigation Operations

Humanitarian Assistance and Disaster Relief

Information Fusion Centre

International Military Education and Training

Islamic State of Iraq and Syria

Intelligence, Surveillance and Reconnaissance

Japan Self Defense Forces

Maritime Domain Awareness

Maritime Security Initiative

North Atlantic Treaty Organization

People's Liberation Army

People's Republic of China

Republic of Korea

Southeast Asia Cooperation and Training

Southeast Asia Maritime Law Enforcement Initiative

United Nations Security Council Resolution

United States Forces Korea

United States Indo-Pacific Command

United States Coast Guard High Endurance Cutter 


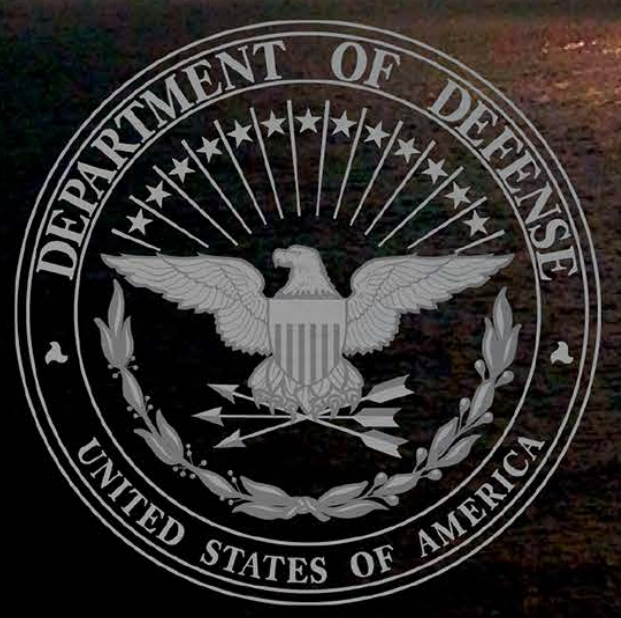

